\title{
AIR POLLUTANTS AND GREENHOUSE GAS EMISSIONS CO-CONTROL EVALUATION IN THE PEOPLE'S REPUBLIC OF CHINA
}

Tao Hu, Xianqiang Mao, Xuedu Lu, Gloria P. Gerilla-Teknomo

NO. 29

December 2020

\section{ADB EAST ASIA WORKING PAPER SERIES}




\section{ADB East Asia Working Paper Series}

\section{Air Pollutants and Greenhouse Gas Emissions Co-control Evaluation in the People's Republic of China}

Tao Hu, Xianqiang Mao, Xuedu Lu, Gloria P. Gerilla-Teknomo

No. 29 | December 2020
Tao Hu and Xianqiang Mao are Asian Development Bank (ADB) consultants who provided knowledge support and technical assistance on the Strategic Policy Study on Collaborative Control of Air Pollution and Carbon Emissions in the Transport Sector.

Xuedu Lu, lead climate change specialist and Gloria P. Gerilla-Teknomo, senior transport sector officer, from the Sustainable Infrastructure Division (EASI), East Asia Department (EARD), ADB, managed this working paper. 
(C) 2020 Asian Development Bank 6 ADB Avenue, Mandaluyong City, 1550 Metro Manila, Philippines

Tel +632 8632 4444; Fax +63286362444

www.adb.org

Some rights reserved. Published in 2020.

Printed in the Philippines

Publication Stock No. WPS200387-2

DOI: http://dx.doi.org/10.22617/WPS200387-2

The views expressed in this publication are those of the authors and do not necessarily reflect the views and policies of the Asian Development Bank (ADB) or its Board of Governors or the governments they represent.

ADB does not guarantee the accuracy of the data included in this publication and accepts no responsibility for any consequence of their use. The mention of specific companies or products of manufacturers does not imply that they are endorsed or recommended by ADB in preference to others of a similar nature that are not mentioned.

By making any designation of or reference to a particular territory or geographic area, or by using the term "country" in this document, $A D B$ does not intend to make any judgments as to the legal or other status of any territory or area.

This work is available under the Creative Commons Attribution 3.0 IGO license (CC BY 3.0 IGO)

https://creativecommons.org/licenses/by/3.0/igo/. By using the content of this publication, you agree to be bound by the terms of this license. For attribution, translations, adaptations, and permissions, please read the provisions and terms of use at https://www.adb.org/terms-use\#openaccess.

This CC license does not apply to non-ADB copyright materials in this publication. If the material is attributed to another source, please contact the copyright owner or publisher of that source for permission to reproduce it. $\mathrm{ADB}$ cannot be held liable for any claims that arise as a result of your use of the material.

Please contact pubsmarketing@adb.org if you have questions or comments with respect to content, or if you wish to obtain copyright permission for your intended use that does not fall within these terms, or for permission to use the ADB logo.

Corrigenda to ADB publications may be found at http://www.adb.org/publications/corrigenda.

Notes:

In this publication, “\$” refers to United States dollars.

ADB recognizes "China" as the People's Republic of China.

The ADB East Asia Working Paper Series is a forum for stimulating discussion and eliciting feedback on ongoing and recently completed research and policy studies undertaken by the East Asia Department of the Asian Development Bank (ADB) staff, consultants, or resource persons. The series deals with key economic and development problems, as well as conceptual, analytical, or methodological issues relating to project/program economic analysis, and statistical data and measurement. The series aims to enhance the knowledge on Asia's development and policy challenges; strengthen analytical rigor and quality of ADB's country partnership strategies, and its subregional and country operations; and improve the quality and availability of statistical data and development indicators for monitoring development effectiveness.

The ADB East Asia Working Paper Series is a quick-disseminating, informal publication whose titles could subsequently be revised for publication as articles in professional journals or chapters in books. The series is maintained by the East Asia Department. 


\section{CONTENTS}

TABLES AND FIGURES

ACKNOWLEDGMENTS V v v v v

$\begin{array}{lll}\text { ABSTRACT } & \text { vi }\end{array}$

ABBREVIATIONS vii

$\begin{array}{lll}\text { I. INTRODUCTION } & 1\end{array}$

II. CONCEPT OF CO-CONTROL $\quad 2$

A. Definition of Co-control 2

B. Evolution of Co-control 3

C. Co-control Evaluation Studies in the Transport Sector 3

III. METHODOLOGY OF CO-CONTROL EVALUATION 4

A. $\quad$ Evaluation Approaches $\quad 4$

B. Evaluation of Physical Synergies $\quad 4$

C. Evaluation of Economic Costs and Benefits 7

D. Application of Co-control Evaluation Methods 9

IV. APPLICATIONS-POLICIES ON ELECTRIC AND FUEL CELL VEHICLES 11

A. Physical Synergy of Air-Pollutant and Greenhouse-Gas Reduction 11

B. Economic Evaluation of Local Air-Pollutant and Greenhouse-Gas Reduction 12

C. Air Pollutant Equivalence 14

$\begin{array}{ll}\text { V. CONCLUSION } & 15\end{array}$

$\begin{array}{ll}\text { APPENDIXES } & 17\end{array}$

1. Data Requirements and Collection 17

2. The Normalization Index and the Weighing Factors for the Transport Sector 19 in the People's Republic of China

3. Emission Factors in this Case Study 24

$\begin{array}{lr}\text { REFERENCES } & 26\end{array}$ 


\section{TABLES AND FIGURES}

\section{TABLES}

$1 \quad$ Methods of Identifying Co-control Measures 10

2 Co-control Significance 10

$\begin{array}{lll}\text { A1.1 Energy Prices } & 17\end{array}$

A1.2 Indirect Emission Parameters of Electricity Generation 17

A1.3 Air Pollutant Equivalence (APeq) Normalizing Parameter 17

A1.4 Basic Technical Parameters of Measures 18

A2.1 Pollution-Source Analysis Results for Several Locations 21

A2.2 Calculations of Particulate Matter 2.5 Contribution Coefficients for the Transport 22 and Power Sectors

A2.3 Values of the Weighing Factors 22

A3.1 Emission Factors from Power Generation, 2017

A3.2 Emission Factors for Vehicles 24

\section{FIGURES}

1 Co-control Effects of Emission-Reduction Technologies 6

2 Marginal Abatement Cost Curve $\quad 9$

3 Comparison of Air-Pollutants and Carbon-Dioxide Emissions for Different Vehicle Types 12

4 Total Cost of Ownership of Different Vehicle Types in the Business-as-Usual Scenario 13

5 Total Cost of Ownership of Different Vehicle Types in the Electric Vehicle-Favorable 14 Scenario

$6 \quad$ Lifetime Air Pollutant Equivalences of Different Vehicle Types 15 


\section{ACKNOWLEDGMENTS}

This working paper was drafted based on the consultant's report of the Asian Development Bank (ADB) technical assistance (TA) project for Strategic Policy Study on Collaborative Control of Air Pollution and Carbon Emissions in the Transport Sector, which was built on the previous studies supported by then the Ministry of Environmental Protection of the People's Republic of China (PRC) (now Ministry of Ecology and Environment) and the Energy Foundation.

Hu Tao and Mao Xianqiang, both consultants for this TA project, and Xing Youkai, research associate at Beijing Normal University, prepared the first draft. Siddiq Khan, consultant, provided inputs to improve this paper.

Yang Jiangang, director, Ministry of Transport of the PRC; Xu Honglei, director, and Wang Renjie, researcher, Transport Planning and Research Institute in the PRC, provided guidance and support for the preparation of this paper.

Xuedu Lu, lead climate change specialist at ADB's East Asia Department (EARD), who led and managed the TA project and the development of this working paper, finalized the paper. Gloria GerillaTeknomo, senior transport officer, EARD, provided technical input and coordinated the development of this publication. Overall guidance and supervision were provided by Sujata Gupta, director, Sustainable Infrastructure Division, EARD.

The authors would like to express their sincere gratitude to the Climate Change Fund, administered by $A D B$, for the support it has given to the TA.

The authors would also like to thank the peer reviewers for their valuable comments and suggestions. 


\begin{abstract}
Greenhouse gas (GHG) emissions from the transport sector are increasing in the People's Republic of China (PRC). While local air pollutant (LAP) emissions from the transport sector are declining in the PRC, the share of transport emissions is increasing compared with the shares of industrial and residential sectors. The PRC has implemented measures for controlling LAPs, and has adopted strategies for mitigating GHG emissions, but LAP reduction and GHG emission control are closely related. To ensure that the national LAP control targets and GHG emission-mitigation commitments are achieved concurrently, the PRC needs to prioritize the application of technologies and measures with significant co-benefits for reducing both LAP and GHG emissions. "Co-control" in this analysis refers to control measures, plans, or policies that seek to maximize the co-benefits of LAP and GHG emission reduction. The co-control studies in the transport sector are limited, but relevant case studies have been done in various other sectors in the PRC, including iron and steel, electricity, cement, and others. These studies demonstrate that there are substantial potentials for strengthening co-benefits by adopting "co-control" measures.

Although "co-control" has been regulated in the newly revised Air Pollution Prevention Law and other government official documents, there is a lack of the knowledge on how to evaluate the co-control performance of various technologies and policies in the transport sector. There is also a lack of methodologies to help the transport policy makers prepare a co-control plan. The lack of evaluation methodologies is among the most critical obstacles to achieving co-control benefits in the transport and other sectors.

In view of the situation, this working paper presents a methodology for co-control evaluation that gauges the benefits of measures for controlling LAPs and mitigating GHG emissions. This methodology is proven to be practical and useful for understanding the maximum achievable benefits of the various technologies and policy actions when co-control is considered in the PRC transport sector. Though the application of the methodology presented in this paper is limited to the transport sector, it could also be applied, directly or indirectly, completely or partially, in other sectors as well.
\end{abstract}

Keywords: co-control, co-benefits, local air pollutants, greenhouse gas, emissions, mitigation, transport sector, People's Republic of China

JEL Classification: Q52, Q53, Q54 


\section{ABBREVIATIONS}

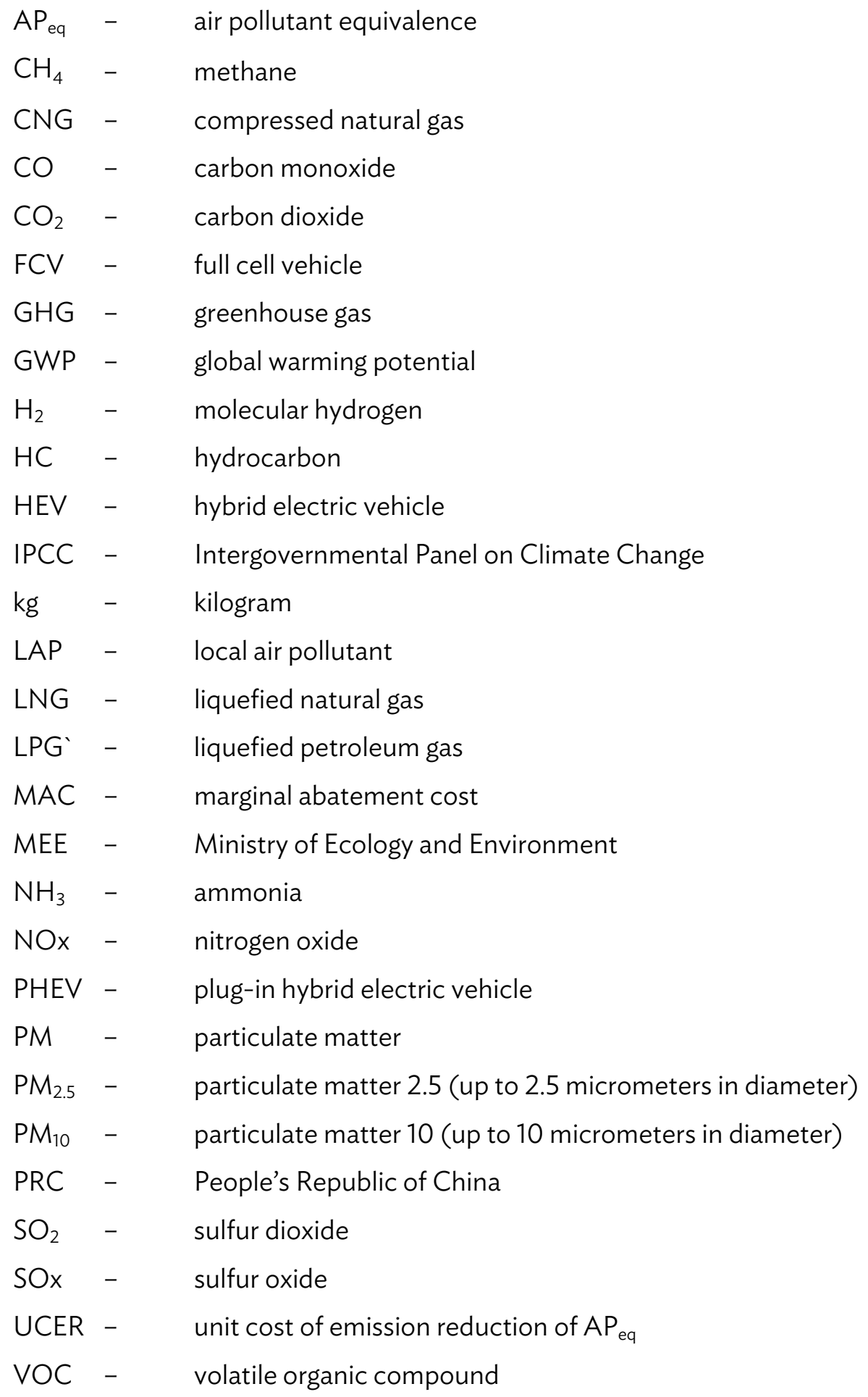




\section{INTRODUCTION}

In the People's Republic of China (PRC), the transport sector is a rapidly growing source of greenhouse gas (GHG) emissions and of local air pollutants (LAPs), including carbon monoxide (CO), hydrocarbon ( $\mathrm{HC}$ ), sulfur oxide (SOx), nitrogen oxide (NOx), ozone, and particulate matter (PM). ${ }^{1}$ The PRC's national vehicle fleet reached 327 million cars and trucks in 2018 (Ministry of Ecology and Environment [MEE] 2019). Emissions of NOx from the transport sector (vehicles, ships, diesel locomotives, and civil aviation aircrafts) reached 7.18 million tons in 2017, accounting for about $40 \%$ of national NOx emissions (MEE et al. 2020). Carbon dioxide equivalent ( $\mathrm{CO}_{2}$-eq) emissions from the transport sector were also high: 827.9 million tons in 2014, accounting for about $7.4 \%$ of national $\mathrm{CO}_{2}$-eq emissions (MEE 2018).

The Government of the People's Republic of China has set national targets to reduce the country's air pollution and GHG emissions. In 2016, the State Council issued the 13th Five-Year Plan for Ecological and Environmental Protection, which had the following air-quality targets: compared with 2015 levels, by 2020 (i) "good air quality days" must reach at least $80 \%$ of each calendar year, totaling 292 days, (ii) $\mathrm{PM}_{2.5}$ emissions must drop by $18 \%$ in cities, and (iii) sulfur dioxide $\left(\mathrm{SO}_{2}\right)$ and $\mathrm{NOx}$ emissions must drop by $15 \%$. ${ }^{2}$ The government's $\mathrm{GHG}$-mitigation targets were to reduce $\mathrm{CO}_{2}$ emissions by $40 \%-45 \%$ by 2020, compared with the 2005 level, and to reach a $\mathrm{CO}_{2}$ emissions peak by around 2030, with a best effort to reach the peak as early as possible, per the government's commitment under the Paris Agreement under the United Nations Framework Convention on Climate Change.

The government has also developed and implemented several polices and measures to control air pollution emitted by the transport sector, such as (i) requiring all imported and domestically produced vehicles to meet the National Standard $\vee(G B-V)$ for vehicle emissions, (ii) monitoring pollutant emissions from vehicles, (iii) limiting the entry of heavy trucks into urban areas, and (iv) supplying high-quality gas and diesel fuel. These initiatives, however, did not consider addressing the GHG emissions from the transport sector concurrently with air pollution control measures.

The government has developed and implemented separate policies and measures specifically to control GHG emissions in the transport sector, such as (i) developing low-carbon and green transport facilities, promoting electric vehicles, and setting strict GHG emission standards for vehicles; (ii) increasing the share of urban public transport to 30\%, improving transport efficiency to reduce GHG emissions per person-kilometer by $5 \%$ and per ton-kilometer by $13 \%$ of road transport by 2020 , and improving railway transport efficiency to reduce GHG emission intensity by $15 \%$ by 2020 , compared with 2010 level. These GHG emission-control initiatives and measures, however, did not concurrently consider reducing air pollutant emissions as a target.

Air-pollution-control and GHG-emission-mitigation measures and technologies can have adverse effects on each other if not designed and applied properly. For instance, vehicle exhaust gas-emission converters and diesel particulate filters can reduce air pollutants, but they might have an adverse impact on $\mathrm{GHG}$ emissions. Converting buses from diesel to natural or biogas fuels might reduce $\mathrm{GHG}$

\footnotetext{
"Sulfur oxide" is an umbrella term for compounds of sulfur and oxygen molecules, among them sulfur dioxide $\left(\mathrm{SO}_{2}\right)$, a common pollutant. "Nitrogen oxide" is an umbrella term encompassing seven polluting gases composed of nitrogen and oxygen, among them nitrogen monoxide (NO), also known as "nitric oxide," and nitrogen dioxide $\left(\mathrm{NO}_{2}\right)$.

2 " $\mathrm{PM}_{2.5}$ " refers to atmospheric particulate matter with a diameter of up to 2.5 micrometers. A micrometer (or micron) equals .001 millimeters.
} 
emissions, but the buses could end up emitting more air pollutants such as NOx. Having commercial vehicles use diesel fuel might be more fuel-efficient, but there is a risk of higher air pollutant emissions. And electric vehicles might not reduce GHG emissions if they are charged with electricity generated from a low-efficiency coal-based power grid. Without a good management system, low-carbon transport practices such as motorcycle sharing may end up producing more waste because of overproduction and short service lives. Some mitigation policies, technologies, and measures that provide emission reduction co-benefits may have high mitigation costs, and might not be adopted if only a single environmental benefit (i.e., only GHG emission reduction or only air pollution reduction) was considered.

To ensure that the national air-pollution control targets and GHG-emission mitigation commitments are concurrently achieved, the PRC needs to prioritize the application of technologies and the implementation of measures with significant co-benefits for reducing both air pollution and GHG emissions. To avoid unintended consequences, the PRC should evaluate the impact of GHG emissions when developing air pollution control policies and evaluate the impact of air pollution emissions when developing GHG-mitigation policies.

"Co-control" seeks to maximize the co-benefits of reducing air pollutants and GHGs. While the co-control studies on the transport sector are very few, relevant case studies have been done in other sectors in the PRC. These case studies have shown that there are substantial potentials for strengthening co-benefits by adopting "co-control" measures.

Although "co-control" has been mentioned in the newly revised Air Pollution Prevention Law and in other government official documents, there is a lack of knowledge on how to evaluate the co-control performance of various technologies and policies in the transport sector. The absence of evaluation methodologies is among the most critical obstacles to achieving co-control benefits in the transport and other sectors.

This working paper presents a methodology of co-control evaluation to better address the complex connection between air pollutants and GHGs. Section II in this paper describes the concept of co-control and the evolution of the concept, and it presents the existing literature on co-control. Section III describes the methodology and its application to some measures that have been adopted by the PRC. Section $V$ then presents the conclusions.

\section{CONCEPT OF CO-CONTROL}

This chapter reviews the definition of "co-control" and the historical development of the concept. It also explains the necessity of co-control evaluation.

\section{A. Definition of Co-control}

Co-control is a control policy, measure, or plan that seeks to maximize the co-benefits of air-pollutant reduction and GHG emissions reduction (Hu et al. 2016). Co-control issues involve various types of air pollutants, so co-control should cover all of them. In addition to air pollutants and GHG emissions, the concept of co-control can be extended to other areas, such as water pollution, soil contamination, social environmental development, and economic development. 


\section{B. Evolution of Co-control}

The evolution of the co-control concept can be divided into three stages:

\section{Stage 1: Ancillary Benefits}

Since the United Nations Framework Convention on Climate Change (UNFCCC) was signed in Rio de Janeiro in 1992, GHG emission reduction has become the key mitigation measure for addressing climate change. In the interest of convincing developing countries to reduce their GHG emissions, there were many discussions about the idea of promoting reduced air pollution as a secondary benefit of GHG reduction, which was called ancillary benefit.

\section{Stage 2: Co-Benefits}

Later, more researchers have found that air pollution reduction could generate GHG reduction as a secondary benefit, and that air pollution reduction measures and GHG reduction measures could benefit each other in a two-way interaction. In 2001, the Intergovernmental Panel on Climate Change (IPCC) published the Third Assessment Report, which included the discussions on the co-benefits of reducing air pollutants and GHGs, and since then the concept has gradually become more popular.

Emission source analysis reveals that LAPs and GHGs share common sources, most notably fossil fuel combustion. Relevant studies around the world have shown that the "co-benefits" or "ancillary benefits" of GHG mitigation are substantial, and can provide a strong motivation for GHG mitigation, which is considered as a "win-win" approach that could attract the attention of policy makers.

\section{Stage 3: Co-control}

Proactively designing control policies, measures, or plans to maximize co-benefits and, even more importantly, to avoid counterbalancing has been recommended (Hu, Tan, and Mao 2012). Thus, the concept of co-control was proposed for achieving maximum co-benefits. Since then, more and more co-control case studies have been done in the PRC and in other Asian countries.

\section{Co-control Evaluation Studies in the Transport Sector}

As indicated above, the purpose of co-control is to maximize co-benefits, but without any quantitative measurement of the benefits of co-control policies, measures, and plans, it is difficult to convince decision-makers to develop and implement those policies, measures, and plans. Hence, an evaluation of any control policy, measure, or plan is important for assessing the relationship between air pollution and GHG reduction to identify whether a policy, measure, or plan, would be able to maximize cobenefits.

Since 2010, research has been carried out to analyze the co-control effects in key sectors in the PRC, including power generation, iron and steel, and transport.

Mao et al. (2012) examined and compared various transport policy instruments that had been implemented in the PRC or were likely to be implemented. These instruments include a carbon tax, energy tax, fuel tax, clean energy vehicle subsidy, and a reduction in ticket prices for public transport. A bottom-up model was applied to a simulated vehicle to predict the emission dynamics for $\mathrm{CO}_{2}$ and local air pollutants under business-as-usual and policy scenarios for the PRC transport sector from 2008 to 2050. The results show that energy and fuel taxes were the two most promising instruments for reducing the intensity of $\mathrm{CO}_{2}$ emissions enough to reach the government's carbon-intensityreduction targets for 2020 . 
Gao et al. (2014) analyzed the co-control effects of 12 typical emission-reduction measures used in the Urumqi public transport system. They developed air pollutant equivalence index to normalize the effects of the emission reductions of the various pollutants.

Tang et al. (2019) assessed the effects of vehicle emission controls on air pollutants and GHG emissions in Hangzhou, and predicted the levels of vehicle-based air pollutants and GHG emissions in 2020 (compared with the 2015 levels) under eight scenarios by using the elastic-coefficient method and the co-benefits coordinate system. The results show that the vehicle emissions of air pollutants and GHGs were reduced under all eight scenarios. The single control scenario, in which old cars with high emissions were eliminated, shows the most significant reduction of air pollutants and GHGs. The scenario involving the elimination of Euro III diesel trucks and the promotion of new energy vehicles (electric vehicles) comes in second.

Kim Oanh et al. (2019) analyzed the emissions of passenger fleets in Bandung, Indonesia, using three emission scenarios against the 2015 baseline. Analysis of potential interventions of technologies under the scenarios: Euro3 (S1), Euro4 (S2), and catalyst revamping (S3), showed the potential co-benefits in the form of air quality improvement and climate forcing mitigation: S1 would reduce toxic pollutant emissions by $62 \%$ and global warming potential (GWP) by $29 \%$; the corresponding reductions would be $68 \%$ and $45 \%$ for $\mathrm{S} 2$ and $47 \%$ and $16 \%$ for $\mathrm{S} 3$.

\section{METHODOLOGY OF CO-CONTROL EVALUATION}

\section{A. Evaluation Approaches}

To evaluate co-control, two key approaches will be applied that include both absolute and relative analyses:

(i) evaluation of physical synergies between air-pollutants and $\mathrm{GHGs}$, measured by $\mathrm{CO}_{2}-$ equivalent $\left(\mathrm{CO}_{2}-\mathrm{eq}\right)$, emission reduction effectiveness, to determine the necessity of co-control;

(ii) evaluation of economic costs (and benefits), which will determine the economic feasibility of co-control.

\section{B. Evaluation of Physical Synergies}

The methods for assessing the effects of co-control include (i) physical co-control effect evaluation methods for LAP and GHG emission reduction, and (ii) cost-effectiveness evaluation methods for reduction measures.

There are three physical co-control effect evaluation methods: a co-control effect coordinate system, cross-elasticity analysis of pollutant emission reduction, and the air pollutant equivalence $\left(A P_{\text {eq }}\right)$, an integrated measuring unit of LAPs and GHGs. The co-control effect coordinate system can reflect the effects of measures in reducing LAPs and GHGs emissions and identify the co-control measures. Cross-elastic analysis of pollutant emission reduction is used to further quantify emission reduction and co-control effectiveness. A pollutant equivalence indicator, $A P_{\text {eq }}$, is formulated to evaluate the co-control effectiveness of multi-pollutant reductions by integrating the air pollutants and GHGs into 
one indicator, using proper weighing factors to reflect the extent of public attention to local air pollutants and GHGs.

The cost-effectiveness evaluation methods for reduction measures include the unit cost of the emission reduction of $A P_{\text {eq }}(U C E R)$, and the marginal abatement cost (MAC) curve. UCER is a quantified assessment indicator that considers both emission reduction benefits and the emission reduction costs of different technologies simultaneously. The MAC curve can easily show the relationship among emission reduction, marginal cost, and the cumulative cost of emission-reduction measures in the coordinate system. Cost-effectiveness analysis has proven to be an important tool for co-control project assessment, and for policy making and decision-making based on economic indicators.

\section{Absolute Physical Evaluation}

The co-control effect coordinate system, as displayed in the graph in Figure 1, lays out the physical cocontrol effects of emission-reduction technologies. In Figure1, the vertical axis shows the extent of $\mathrm{CO}_{2}$-eq reduction, with greater reduction as moving upward along the axis; and the horizontal axis shows the extent of LAP reduction, with greater reduction as moving to the right along that axis. Thus, the space above the horizontal axis implies a reduction in $\mathrm{CO}_{2}$-eq emissions, while the space below implies an increase in $\mathrm{CO}_{2}$-eq emissions; and the space to the right of the vertical axis implies a reduction in LAP, while the space to the left implies an increase. A point falling on the vertical axis would mean that LAP does not increase or decrease, and a point falling on the horizontal axis would mean the same for $\mathrm{CO}_{2}$-eq. Each labeled point shown in the graph represents a technology aimed at reducing LAP and $\mathrm{CO}_{2}$-eq emissions. The points falling within the first (upper-right) quadrant represent technologies that are able to reduce both; the point located in the second (upper-left) quadrant represents a technology that reduces $\mathrm{CO}_{2}$-eq emissions, but not LAP emissions, which keeps increasing; the point shown in the fourth (lower-right) quadrant represents a technology that reduces LAP emissions, but not $\mathrm{CO}_{2}$-eq emissions, which keeps increasing. Finally, the point in the third (lower-left) quadrant represents a technology that reduces neither LAP nor $\mathrm{CO}_{2}$-eq emissions, as both keep increasing.

In Figure 1, in the first quadrant, the angle between the horizontal axis and each line leading from the origin to a point represents the reduction significance of a technology: the larger the angle, the greater the $\mathrm{CO}_{2}$-eq reduction. Technologies $\mathrm{E}$ and $\mathrm{A}$ of Figure 1 reduce the same LAP (say, two units of $\mathrm{SO}_{2}$ ), but $\mathrm{E}$ has greater success in reducing $\mathrm{CO}_{2}$-eq (say, $\mathrm{E}$ reduced it by four units, but $\mathrm{A}$ by only one). The integrated reduction effects of $E$ are then deemed better than those of $A$. If two points have the same angle (i.e., they fall along the same line), the technology represented by the point farther from the origin has the greater co-control effects. For example, in Figure 1, technologies $N$ and $M$ have the same ratio of $\mathrm{CO}_{2}$-eq emission reduction units over their LAP reduction units, but $\mathrm{N}$ reduces both LAP and $\mathrm{CO}_{2}$-eq emissions by greater amounts than $\mathrm{M}$. 
Figure 1: Co-control Effects of Emission-Reduction Technologies

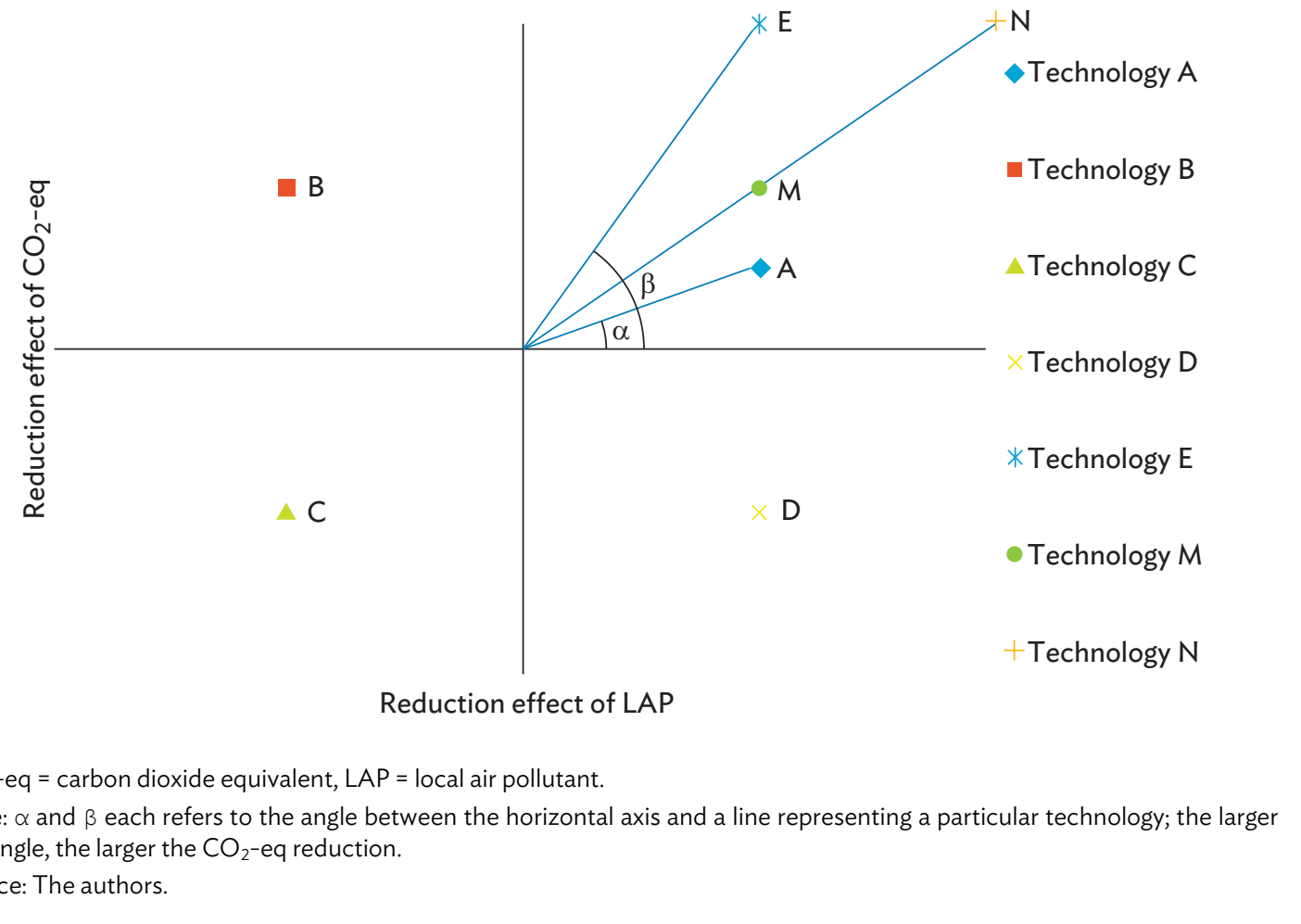

\section{Relative Physical Evaluation}

Pollutant reduction cross elasticity $\left(E l s_{a / b}\right.$ ) is used to evaluate the co-control effectiveness of measures aimed at reducing LAPs and $\mathrm{CO}_{2}$-eq. The subscripts "a" and "b" represent different pollutants. Like the co-control effects graph in Figure 1, $E l s_{a / b}$ can reflect the effectiveness of the co-control of various measures. $E l s_{a / b}$ is calculated as follows:

$$
\begin{aligned}
& E l s_{\mathrm{SO}_{2} / \mathrm{CO} 2-e q}=\frac{\Delta S O 2 / \mathrm{SO} 2}{\Delta \mathrm{CO} 2-e q / \mathrm{CO} 2-e q} \\
& E l s_{\mathrm{NOX} / \mathrm{CO} 2-e q}=\frac{\Delta \mathrm{NOX} / \mathrm{NOX}}{\Delta \mathrm{CO} 2-e q / \mathrm{CO} 2-e q} \\
& E l s_{P M / C O 2-e q}=\frac{\Delta P M / P M}{\Delta C O 2-e q / C O 2-e q} \\
& E l s_{H C / C O 2-e q}=\frac{\Delta H C / H C}{\Delta C O 2-e q / C O 2-e q} \\
& E l s_{L A P / C O 2-e q}=\frac{\Delta L A P / L A P}{\Delta C O 2-e q / C O 2-e q}
\end{aligned}
$$


where $E l s_{a / b}$ is the pollution reduction cross elasticity, $\triangle C O 2-e q / C O 2-e q$ is the rate of change in $\mathrm{CO}_{2}$-eq emissions, $\triangle \mathrm{SO} 2 / \mathrm{SO} 2$ is the rate of change in $\mathrm{SO}_{2}$ emissions, $\triangle N O x / N O x$ is the rate of change in NOx emissions, $\triangle P M / P M$ is the rate of change in emissions of particulate matter (PM), $\triangle H C / H C$ is the rate of change in hydrocarbon $(\mathrm{HC})$ emissions, ${ }^{3}$ and $\triangle L A P / L A P$ is the rate of change in the emissions of LAPs.

Equation (1) denotes the reduction cross elasticity of measures aimed at reducing $\mathrm{SO}_{2}$ and $\mathrm{CO}_{2}$-eq; equation (2) denotes the reduction cross elasticity of measures aimed at reducing $\mathrm{NOx}$ and $\mathrm{CO}_{2}$-eq; equation (3) denotes the reduction cross elasticity of measures aimed at reducing $\mathrm{PM}$ and $\mathrm{CO}_{2}$-eq; equation (4) denotes the reduction cross elasticity of measures aimed at reducing $\mathrm{HC}$ and $\mathrm{CO}_{2}$-eq; and equation (5) denotes the reduction cross elasticity of measures aimed at reducing LAPs and $\mathrm{CO}_{2}$-eq.

If $E l s_{a /}>0$, it means that the measure can reduce the emissions of pollutants $a$ and $b$ at the same time.

If $E l s_{a / b} \leq 0$, it means that the measure cannot reduce the emissions of pollutants $a$ and $b$ simultaneously, thus no co-control effect exists.

If $E$ l $s_{a / b}=1$, it means that the measure has exactly the same emission reduction effectiveness for pollutant $\mathrm{a}$ and $\mathrm{b}$.

If $0<E l s_{a / b}<1$, it means that the measure can reduce more emissions of pollutant $b$ than those of pollutant $a$.

If $E l s_{a / b}>1$, it means that the measure can reduce more emissions of pollutant a than those of pollutant $b$.

When the numerator and the denominator are both negative (although $\mathrm{E} l_{s_{a / b}}>0$ ), it means that the measure increases the emissions of both types of pollutants at the same time. This measure is thus referred to as an "anti-co-control" measure.

\section{Evaluation of Economic Costs and Benefits}

\section{Calculation of $\mathrm{AP}_{\mathrm{eq}}$}

The co-control effectiveness of multi-pollutant reduction measure is evaluated by means of the reduction of $\mathrm{AP}_{\mathrm{eq}}$, which is formulated by integrating all the pollutants (i.e., $\mathrm{SO}_{2}, \mathrm{NOx}, \mathrm{CO}, \mathrm{PM}, \mathrm{HC}$, and $\mathrm{CO}_{2}$ ) into one, as following:

$$
\begin{gathered}
A P_{e q}=R_{L A P} \cdot \sum A_{i j} \cdot Q_{L A P}+R_{G H G} \cdot \sum Q_{G H G} \\
A P_{e q}=R_{L A P} \cdot A_{i j} \cdot\left(\alpha Q_{S O 2}+\beta Q_{N O x}+\gamma \mathrm{QCO}+\delta Q P M+\varepsilon Q H C+\cdots\right)+R_{G H G} \cdot\left(\epsilon \mathrm{QCO}_{2}+\cdots\right)
\end{gathered}
$$

where $A P_{\text {eq }}=$ air pollutant equivalence; $R_{L A P}, R_{G H G}=$ the relative weighing factors of LAPs and GHGs; $Q_{L A P}, Q_{G H G}=$ the emission of LAPs and $G H G s ; A_{i, j}=$ the air pollution contribution of $i$ industry in $j$ area, which related to the meteorological conditions and natural topography of the region, and to the spatial location and emission characteristics of the industry; $\alpha, \beta, \gamma, \delta, \varepsilon, \cdots=$ the weighing factors of the air pollutants; and $\in \cdots=$ the weighing factors of the GHGs.

\footnotetext{
3 "Hydrocarbon" is an umbrella term that includes organic chemical compounds containing only hydrogen and carbon.
} 
Equations (6) and (7) are basic formulas that can be expanded to involve as many pollutants as needed, depending on the scope covered by the reduction measure. The relative weighing factors $R_{\text {LAP }}$ and $\mathrm{R}_{\mathrm{GHG}}$ are intended to reveal the relative importance of the pollutants in terms of social welfare loss. Appendix 2 provides more details on deciding the factors $R_{L A P}$ and $R_{G H G}$.

Different GHGs have different GWP values, but the same GHG has the same warming effect no matter where the GHG emits from, and their contributions to climate change will be the same. For LAPs, however, the sector, industry, and geographic location do matter. The effects of air pollutants emitted in the same quantities from different sources will not be the same. For instance, emissions from elevated sources (such as power plants) will have less impact on public health than motor-vehicle exhaust emissions. Similarly, the same amount of LAP emissions will have a stronger impact on public health in cities, where population densities are higher than rural areas. Overall, areas where emissions are easily diffused will suffer less harm to public health than areas where diffusion is difficult. So, when considering the impacts based on sector, industry, and geographic location, an adjustment factor, $\mathrm{A}_{\mathrm{i}, \mathrm{j}}$, can be determined by a diffusion model. The weighing factors $\alpha, \beta, \gamma, \delta, \varepsilon \ldots$ essentially reflect the pollutant-control priority in decision-making based on the amount of social welfare loss. Determining the values of the weighing factors $\alpha, \beta, \gamma, \delta, \varepsilon \ldots$ is not as complicated as in welfare economics, but it can sometimes be highly controversial and disputable. A commonly accepted rule is that the weighing factors must take externalities into account and be assigned in accordance with the impacts of each pollutant on human health. $\mathrm{AP}_{\text {eq }}$ normalizing parameters and data sources for PRC's transport sector and power industry are included in Appendix 1.

\section{Economic Evaluation}

UCER is used to gauge the cost effectiveness of reduction measures. In this study, it is used to determine the cost (in CNY) of emission reduction of one kilogram of $A P_{\text {eq. }}$ UCER is calculated by dividing the reduction cost (in CNY) by the corresponding $A P_{\text {eq }}$ reduction for each reduction measure. The UCER for technology $i$ is thus calculated through the following formula:

$$
U C E R_{i}=\frac{C C_{i}-M B_{i}}{Q_{i}}
$$

where, $C C_{i}=$ the annual cost of technology $\mathrm{i}$, including investment costs and operation and maintenance costs; $M B_{i}=$ the annual economic benefits of technology $i$, such as energy saving benefits; and $Q_{i}=$ the reduction effect of technology $i$ in terms of $A P_{\text {eq. }}$.

Essentially, UCER considers the effectiveness and cost of reduction technologies. The technologies with lower UCERs should be preferred over those with higher UCERs in a least-cost emissionreduction scheme. 


\section{Marginal Abatement Cost (MAC)}

The MAC curve can be drawn based on the emission reduction potentials and unit costs.. The emission reduction potentials of measures reflect the maximum effect that can be achieved. The calculation is done through the following formula:

$$
M A X_{E M i}=\left(M A X Q_{i}-Q_{O}\right) R_{i}
$$

where $M A X_{E M i}=$ the abatement potential of of $A P_{\text {eq }}$ when measure $i$ is applied; $M a x Q_{i}=$ the largest market share that can be achieved with measure $i ; Q_{0}=$ the market share achieved with measure $i$ in the base year; and $R_{i}=$ the rate of emission reduction of $A P_{\text {eq }}$ achieved by measure $i$.

The $\mathrm{AP}_{\text {eq }}$ abatement potential of a specific technology or measure corresponds to its maximum achievable $A P_{\text {eq }}$ reduction, which depends on the maximum achievable incremental market share and the abatement rate.

When the abatement technologies and measures are arranged in the order of increasing UCER, using the abatement potential as the abscissa and the UCER value as the ordinate, a MAC curve can be created (Figure 2). This curve shows that an incremental application of a control technology or measure results in incremental pollutant reductions, and consequently, in incremental costs.

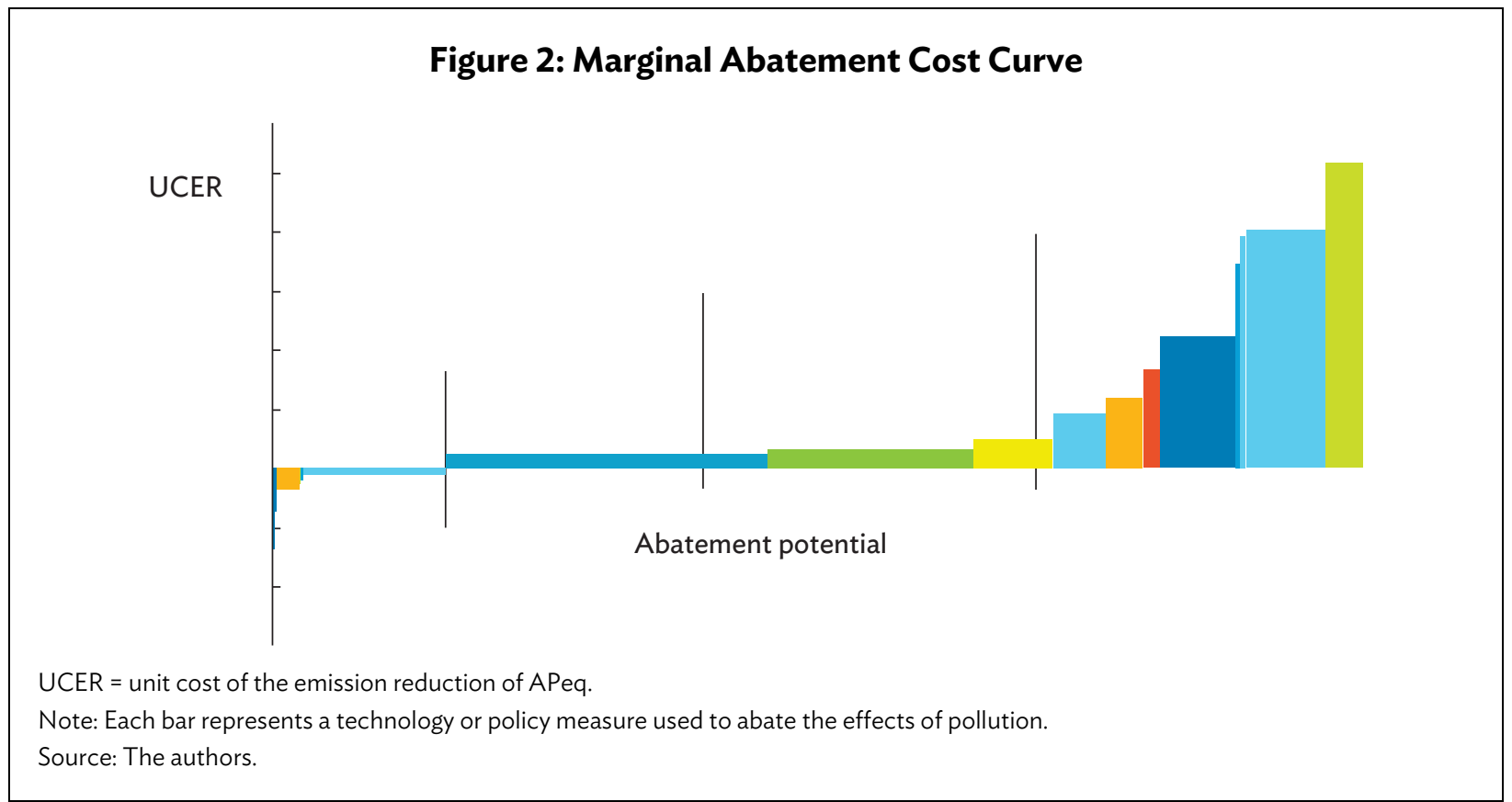

\section{Application of Co-control Evaluation Methods}

Physical co-control evaluation methods-such as the co-control effects coordinate system (i.e., the graph in Figure 1), the concept of $A P_{\text {eq }}$, and cross-elastic analysis of pollutant emission reduction-can be used to justify if measures are qualified as co-control measures. Table 1 summarizes the methods of identifying co-control measures. 
Table 1: Methods of Identifying Co-control Measures

\begin{tabular}{|c|c|c|c|c|}
\hline \multirow{2}{*}{$\begin{array}{l}\text { Extent } \\
\text { to which } \\
\text { Measures are } \\
\text { Co-control }\end{array}$} & \multirow[b]{2}{*}{ Results } & \multicolumn{3}{|c|}{ Methods of Co-control Evaluation } \\
\hline & & Coordinate System & Cross-Elastic Analysis & $\begin{array}{l}\text { Emission reduction of } \\
\qquad A P_{\mathrm{eq}}\end{array}$ \\
\hline $\begin{array}{l}\text { Strong } \\
\text { co-control }\end{array}$ & $\begin{array}{l}\text { All air pollutants and } \\
\text { greenhouse gases have } \\
\text { been reduced. }\end{array}$ & $\begin{array}{l}\text { The points representing } \\
\text { these measures are located } \\
\text { in the first quadrant of } \\
\text { Figure } 1 .\end{array}$ & $E L_{a / b}>0^{*}$ & $A P_{\text {eq }}$ reduction $>0$ \\
\hline $\begin{array}{l}\text { Weak } \\
\text { co-control }\end{array}$ & $\begin{array}{l}\text { While most pollutants are } \\
\text { reduced, one or more have } \\
\text { increased. But emission } \\
\text { reduction of AP } \text { is } \\
\text { "positive" or "zero"; that is, } \\
\text { the net effect is positive or } \\
\text { zero. }\end{array}$ & $\begin{array}{l}\text { The points representing } \\
\text { these measures are located } \\
\text { either in the second or } \\
\text { fourth quadrant of Figure } 1 .\end{array}$ & $\mathrm{EL}_{\mathrm{a} / \mathrm{b}} \leq 0$ & $A P_{\text {eq }}$ reduction $\geq 0$ \\
\hline $\begin{array}{l}\text { Non-co- } \\
\text { control }\end{array}$ & $\begin{array}{l}\text { While most pollutants have } \\
\text { been reduced, one or more } \\
\text { have increased. The } \\
\text { emission reduction of } \mathrm{AP}_{\text {eq }} \\
\text { is "negative"; that is, the net } \\
\text { effect is negative. }\end{array}$ & $\begin{array}{l}\text { The points representing } \\
\text { these measures are located } \\
\text { in either the second or } \\
\text { fourth quadrant of Figure } 1 .\end{array}$ & $E L_{a / b}<0$ & $A P_{\text {eq }}$ reduction $<0$ \\
\hline $\begin{array}{l}\text { Anti-co- } \\
\text { control }\end{array}$ & $\begin{array}{l}\text { One or several or all of the } \\
\text { pollutants have increased. } \\
\text { The emission reduction of } \\
A P_{\text {eq }} \text { is "negative", that is, } \\
\text { the net effect is negative. }\end{array}$ & $\begin{array}{l}\text { The points representing } \\
\text { these measures are located } \\
\text { in the third quadrant of } \\
\text { Figure } 1 .\end{array}$ & $\begin{array}{l}\text { Both the numerator } \\
\text { and denominator are } \\
\text { negative. }\end{array}$ & $A P_{\text {eq }}$ reduction $<0$ \\
\hline
\end{tabular}

$\mathrm{EL}_{\mathrm{a} / \mathrm{b}}=$ the pollution reduction cross elasticity, $\mathrm{AP}_{\mathrm{eq}}=$ air pollutant equivalence.

Source: The authors.

In addition, the co-control evaluation methods can also be used to analyze the degree of a co-control measure's effectiveness. Table 2 shows how significant a co-control measure will be based on results of the evaluation methods.

Table 2: Co-control Significance

\begin{tabular}{|l|l|}
\hline Evaluation Methods & \multicolumn{1}{c|}{ Significance of Co-control } \\
\hline Coordinate system (Figure 1) & $\begin{array}{l}\text { The distance from the origin of the point representing a co- } \\
\text { control measure } \\
\text { The angle between the } x \text { axis or the y axis and the line between } \\
\text { the origin and the point }\end{array}$ \\
\hline Cross-elastic analysis & The value of the $E L_{a / b}$ \\
\hline$A P_{\text {eq }}$ & The value of the emission reduction of $\mathrm{AP}_{\text {eq }}$ \\
\hline UCER & The value of UCER \\
\hline
\end{tabular}

$\mathrm{EL}_{\mathrm{a} / \mathrm{b}}=$ the pollution reduction cross elasticity, $\mathrm{AP}_{\mathrm{eq}}=$ air pollutant equivalence, $\mathrm{UCER}=$ unit cost of emission reduction of $A P_{\mathrm{eq}}$. Source: The authors. 


\section{APPLICATIONS-POLICIES ON ELECTRIC AND FUEL CELL VEHICLES}

The previous section discusses the evaluation methods of air-pollutants, and GHGs, $A P_{\text {eq }}$ and costeffectiveness. In this section, the methods will be applied to demonstrate the significant difference of conventional (gasoline-fueled internal combustion engine) and advanced (hybrid electric vehicles, battery electric vehicles, fuel cell vehicles) vehicle technologies on reducing air pollution and GHG emissions. The co-control costs and benefits of gasoline, electric, and fuel cell vehicles will also be assessed and illustrated.

Gasoline-fueled internal-combustion engines have dominated personal transport for a long time. Concerns about the air pollution and GHGs emanating from these vehicles, plus government efforts to reduce the energy consumption in the transport sector, have prompted automakers to consider alternative fuel vehicles. Driven by fuel economy regulations across the world and by the competition from new and emerging technologies, gasoline passenger vehicles have incorporated engine improvements and, as a result, have considerably improved their fuel economies. Today's gasoline vehicles are significantly more fuel efficient than comparable cars at the beginning of this century. Hybrid technologies have become commonplace in most automaker light-duty lineups, and both electric vehicles and plug-in hybrid electric vehicles ( $\mathrm{PHEVs}$ ) have received renewed attention, as they offer partial or full independence from petroleum fuels. Fuel cell vehicles (FCVs) with onboard hydrogen fuel is another cutting-edge technology that can substantially reduce life-cycle air pollution and GHG emissions. In this case study, the co-control evaluation methodology was applied to compare the new and emerging vehicle technologies-including hybrid electric vehicles (HEVs), electric vehicles, PHEVs, and FCVs - with conventional gasoline vehicles to identify the differences in their emissions reduction benefits and costs of ownership.

\section{A. Physical Synergy of Air-Pollutant and Greenhouse-Gas Reduction}

Fuel combustion in conventional gasoline vehicles, HEVs, and PHEVs generate air pollution and GHG emissions, while electric vehicles and FCVs do not produce any tailpipe emissions. However, given that electric vehicles obtain their electricity from wall-mounted chargers, they can contribute indirectly to air pollution and GHG emissions from the generation of the charged electricity, though subject to the power generation mix. A fair comparison of these vehicles should therefore be on a "well-to-wheels" basis (i.e., encompassing the full fuel cycle). Figure 3 shows the emissions of carbon monoxide (CO), $\mathrm{CO}_{2}$, NOx, particulate matter $2.5\left(\mathrm{PM}_{2.5}\right)$, and sulfur oxide ( $\mathrm{SOx}$ ) generated by a conventional gasoline vehicle, $\mathrm{HEV}, \mathrm{PHEV}$, electric vehicle, and $\mathrm{FCV}$. As seen in the figure, the electric vehicle produced the least amount of $\mathrm{NOx}$ and $\mathrm{CO}_{2}$, while the $\mathrm{FCV}$ and $\mathrm{HEV}$ produced the lowest $\mathrm{PM}_{2.5}$ and $\mathrm{SO}$ emissions. The conventional gasoline vehicle, on the other hand, produced the highest amount of air pollution and $\mathrm{CO}_{2}$ emissions. For the calculations of $\mathrm{CO}_{2}$ emissions from electric vehicles, the $\mathrm{CO}_{2}$ emissions from electricity generation in the PRC were applied; as there were no public data available on molecular hydrogen $\left(\mathrm{H}_{2}\right)$ production in the PRC, the $\mathrm{CO}_{2}$ emissions from $\mathrm{H}_{2}$ production were calculated based on the data of the United States, although $\mathrm{CO}_{2}$ emissions from $\mathrm{H}_{2}$ production in the PRC would be higher than that in the United States. 


\section{Figure 3: Comparison of Air Pollutants and Carbon Dioxide Emissions for Different Vehicle Types}

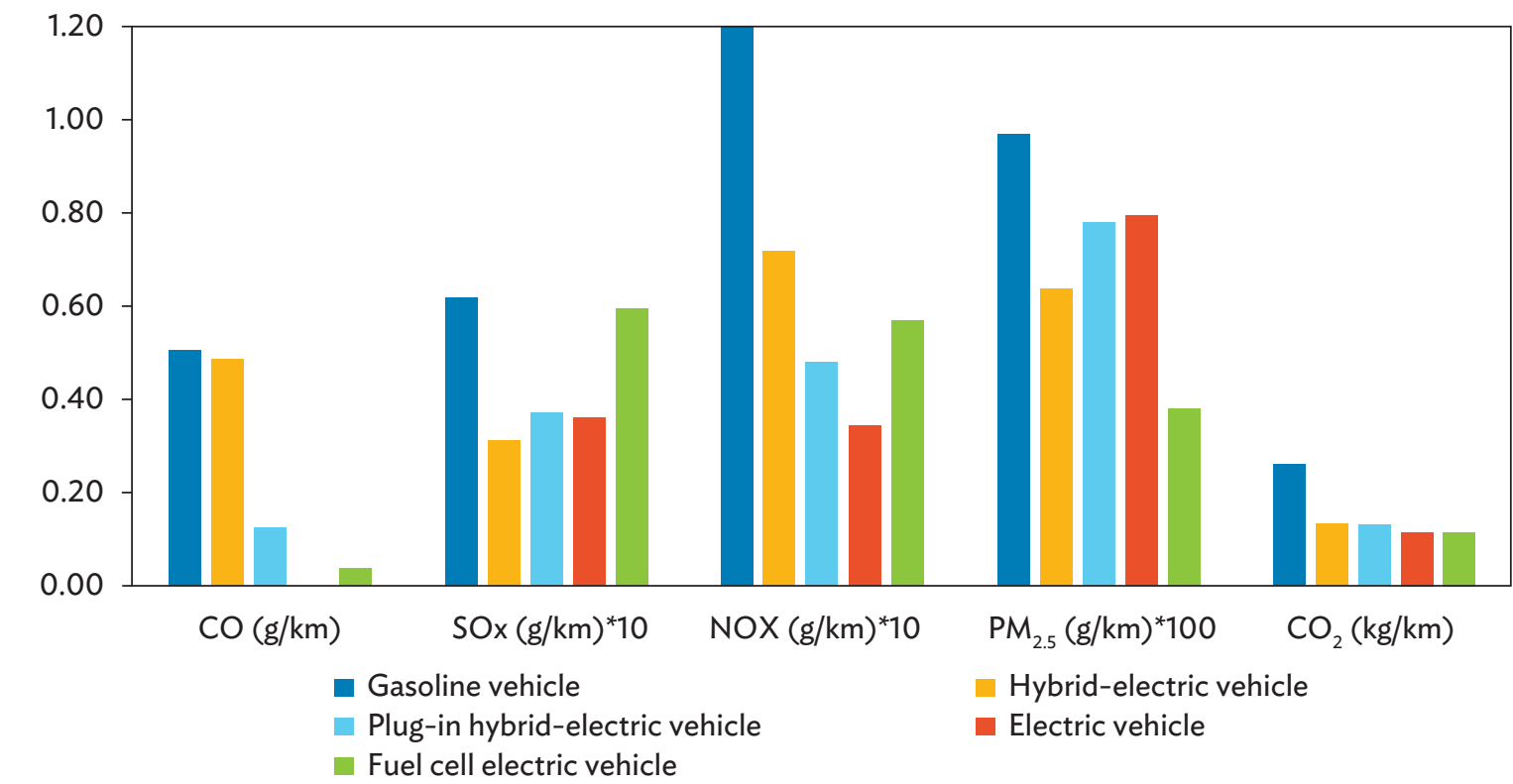

$\mathrm{CO}=$ carbon monoxide, $\mathrm{CO}_{2}=$ carbon dioxide, $\mathrm{g}=$ gram, $\mathrm{kg}=$ kilogram, $\mathrm{km}=$ kilometer, $\mathrm{NOx}=$ nitrogen oxide, $\mathrm{PM}_{2.5}=$ particulate matter 2.5 (up to 2.5 micrometers in diameter), $\mathrm{SOx}=$ sulfur oxide.

Note: The calculations for this figure are based on data from the China Electricity Council (People's Republic of China), Henan Provincial Department of Transportation, and the "Greenhouse gases, Regulated Emissions, and Energy use in Transportation" (GREET) model from the Argonne National Laboratory.

${ }^{a}$ In this figure, SOx and NOx are shown at 10 times the actual amounts, and $\mathrm{PM}_{2.5}$ at 100 times, for better visualization.

Source: The authors.

\section{B. Economic Evaluation of Local Air-Pollutant and Greenhouse-Gas Reduction}

This section discusses the total cost of ownership of the five vehicle types discussed above and their relationship with air pollution and $\mathrm{CO}_{2}$ emission reductions. The total cost of owning each vehicle type was calculated by combining the purchase price (not including taxes and duties), the cost of fuel, the cost of replacing tires and batteries, and the average cost of maintenance. It was assumed that all the vehicles had been driven for 180,000 kilometers $(\mathrm{km})$ during their lifetimes and had had one battery replacement, ${ }^{4}$ which is considered as a reasonable assumption, given that most electric vehicle models offer a battery warranty for most of the vehicle's lifetime. ${ }^{5}$ In order to determine the total fuel costs, each vehicle's fuel economy as recorded in the specifications was used. The price of electricity was assumed to be $\$ 0.08$ per kilowatt hours and the gasoline price was assumed to be $\$ 1.0$ per liter. ${ }^{6}$ Figure 4 compares the results regarding the total cost of ownership of conventional gasoline vehicles, HEVs, EVs, PHEVs, and FCVs. The HEVs offered the lowest cost of ownership, followed by electric vehicles, while hydrogen FCVs had the highest cost of ownership, more than double the cost for HEVs

4 The figure of 180,000 lifetime $\mathrm{km}$ is based on a 15-year life, with 12,000 km driven per year.

5 Which Electric Offers the Best Warranties? https://insideevs.com/news/342221/which-electric-cars-offer-the-bestwarranties/

6 Statista. Global Electricity Prices in 2018, by Select Country. https://www.statista.com/statistics/263492/electricityprices-in-selected-countries/; and GlobalPetrolPrices.com. 2020. China Gasoline Prices. 4 May. https://www.globalpetrolprices.com/China/gasoline_prices/. 
(Figure 4). This calculation did not include the costs of electric vehicle or PHEV charging or of FCV refueling, which would have increased the costs of owning these vehicles, especially the FCVs. These costs do suggest, however, that vehicle taxes and duties could be used as co-control policy tools, either to discourage purchases of polluting vehicles or to encourage purchase of cleaner vehicles. These examples involve "best-in-class" vehicles, as can be seen from their high fuel efficiency. The cost of owning an average vehicle would thus likely be higher than the costs arrived at in these calculations.

However, the electric vehicles offered the lowest cost of ownership under the electric vehiclefavorable scenario (Figure 5), which was assumed that declining battery prices would reduce battery costs by $33 \%$, causing electric vehicle purchase prices to go down by $20 \%$ and battery replacement prices down by $50 \%$. The retail electricity price was assumed to drop by $20 \%$, while the price of gasoline was assumed to be on a declining trend.

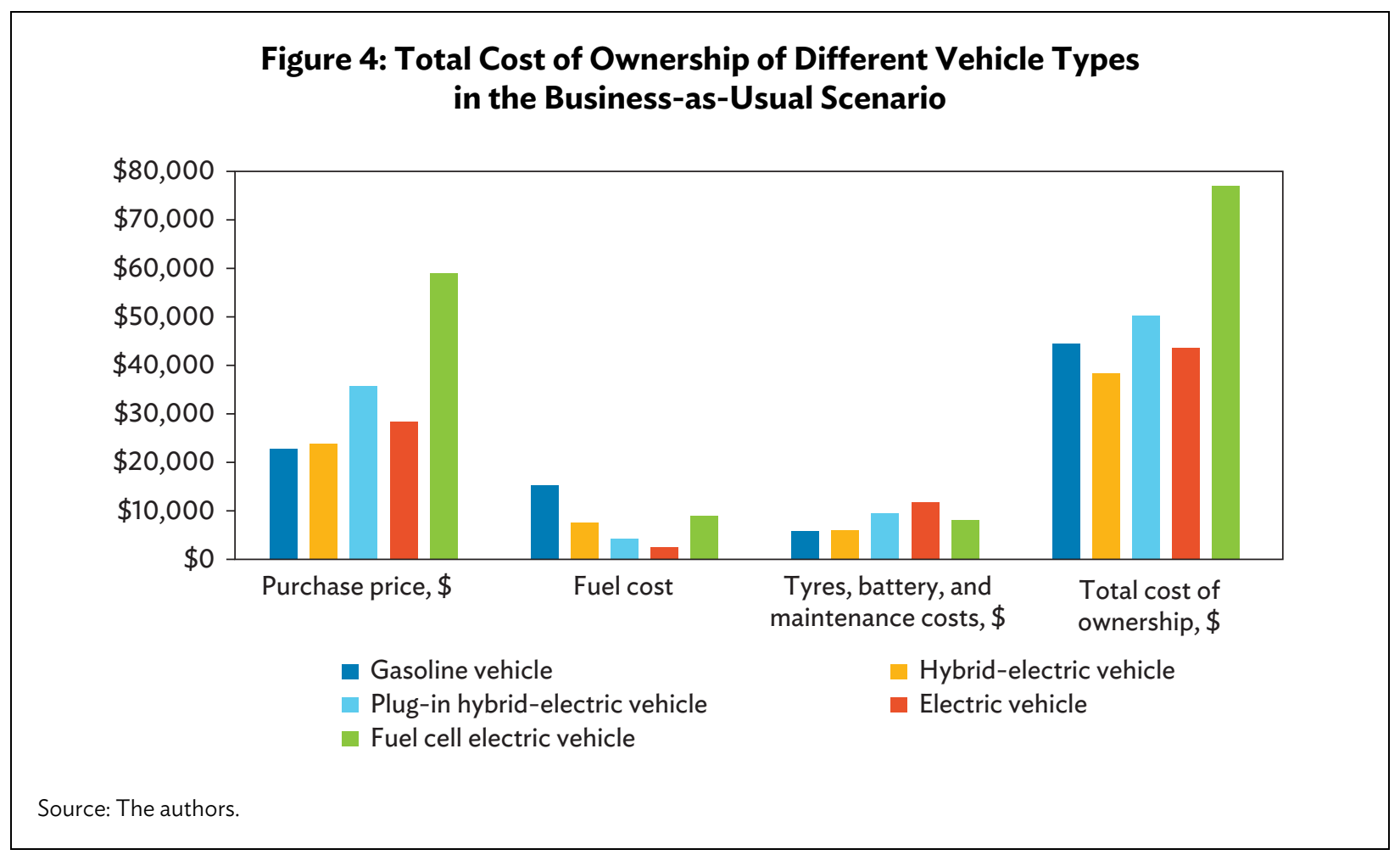




\section{Figure 5: Total Cost of Ownership of Different Vehicle Types in the Electric Vehicle-Favorable Scenario}

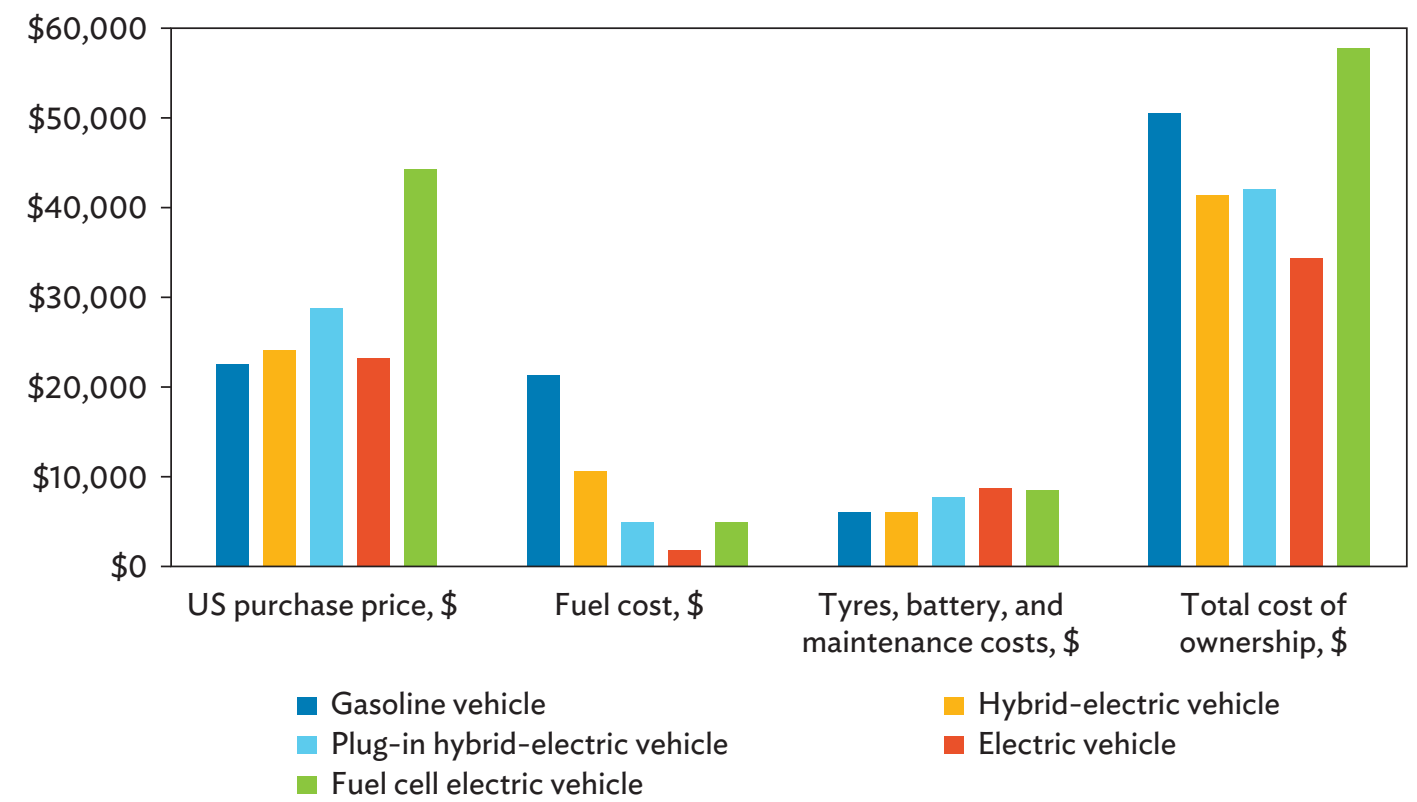

Source: The authors.

\section{Air Pollutant Equivalence}

The $\mathrm{AP}_{\text {eq }}$ for each vehicle type was calculated by integrating all the pollutants generated by each type into one. To that end, relative weighing factors were set for all the pollutants, depending on their relative externalities. For calculation purpose, the weighing factors were established as shown in Appendix 2. Lifetime emissions from these vehicles were multiplied by these weighing factors to calculate the $A P_{\text {eq }}$ for each vehicle type in the business-as-usual (i.e., baseline) scenario and an electric vehicle-favorable scenario. The business-as-usual scenario reflected the current conditions of development of all the types of vehicles, while in the electric vehicle-favorable scenario, government policies on electric vehicle development were given high priority with subsidies. As seen in Figure 6, electric vehicles achieved the maximum pollution reductions under both the business-as-usual and electric vehicle-favorable scenarios, followed by FCVs and HEVs. 
Figure 6: Lifetime Air Pollutant Equivalences of Different Vehicle Types

$\left(1,000\right.$ units of $\left.A P_{e q}\right)$

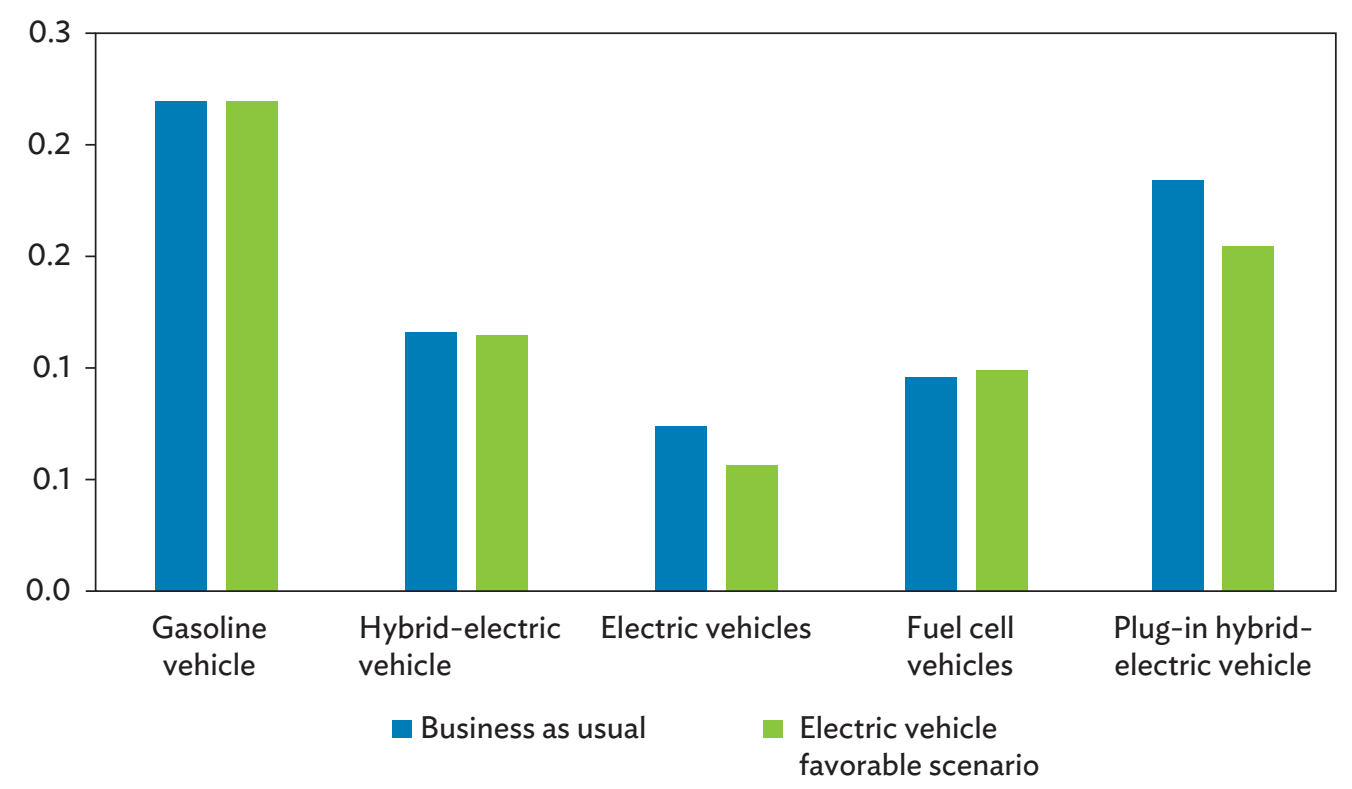

Source: The authors.

\section{CONCLUSION}

Although "co-control" has been cited in the newly revised Air Pollution Prevention Law and other government official documents in the PRC, there is a lack of knowledge on how to evaluate the co-control performance of various technologies and policies in the transport sector. There is also a lack of methodologies to help transport decision-makers engage in co-control planning on sound technical basis.

The methodology developed in this study represents a significant step forward in co-control evaluation. This study features improved approaches and ways to decide weighing parameters for air pollutants and GHGs, that draw on the latest research in the PRC on air-pollution prevention (e.g., the government research behind the Environmental Protection Tax Law) and on international research on climate change (e.g., the Intergovernmental Panel on Climate Change [IPCC] Fifth Assessment Report).

The analysis on co-control benefits of electric vehicles and FCVs in this study shows that these advanced vehicles offer viable alternatives to traditional gasoline-fueled internal-combustion passenger vehicles. Electric vehicles and FCVs provide zero tailpipe emissions; and more importantly, they can reduce petroleum dependence. These vehicles, especially electric vehicles, also offer GHG emissions reduction and air-quality benefits on a well-to-wheels basis, even if those benefits depend on the electricity generation mix for electric vehicles, and on hydrogen production for hydrogen FCVs. While the electric vehicles and FCVs have the lowest operating costs, their high purchase costs may hamper their market share and their potentials of improving air quality and climate protection would not be realized. 
The PRC has been investing in renewable energy sources to reduce dependence on coal and on gasoline. The PRC's transition from coal to renewables in electricity generation would significantly improve the GHG-emission and air-quality benefits of electric vehicles. While the up-front costs of these new advanced vehicles and of clean electricity generation remain major challenges to the adoption of electric vehicles, government subsidy to lower purchase price and decline battery price would help reduce the up-front costs and, as a result, enable electric vehicles to offer the lowest cost of ownership under the electric vehicle-favorable scenario. Consequently, electric vehicles would provide the maximum net benefit of $A P_{\text {eq }}$ reduction under the electric vehicle-favorable scenario.

In conclusion, this working paper presents a methodology for co-control evaluation that demonstrates the benefits of measures for controlling LAPs and mitigating GHG emissions. This methodology is proven to be practical and useful for maximizing the benefits of the measures and strategies to reduce air pollutants and GHGs emissions in the PRC transport sector. Though the application of the methodology in this paper is limited to the transport sector in the PRC, it could also be applied, directly or partially, in other sectors and other countries and regions by necessary adjustments in parameters. 


\section{APPENDIX}

\section{Appendix 1: Data Requirements and Collection}

The data required for co-control evaluation include the basic technical parameters of different co-control measures, energy prices, indirect emission parameters of electricity generation, and the normalized parameters for the air pollutant equivalence $\left(A P_{\text {eq }}\right)$. The data sources are listed in Tables A1.1, A1.2, and A1.3.

Table A1.1: Energy Prices

\begin{tabular}{|l|l|}
\hline Energy Types & \multicolumn{1}{c|}{ Data Sources } \\
\hline Gasoline & (i) Market prices \\
\hline Kerosene & \\
\cline { 1 - 1 } Diesel & \\
\cline { 1 - 1 } Fuel oil & \\
\cline { 1 - 1 } Compressed natural gas & \\
\hline Electricity & \\
\hline Liquefied natural gas & \\
\hline Liquefied petroleum gas & \\
\hline Hydrogen $\left(\mathrm{H}_{2}\right)$ & \\
\hline
\end{tabular}

Source: The authors.

Table A1.2: Indirect Emission Parameters of Electricity Generation

\begin{tabular}{|c|c|c|}
\hline \multicolumn{2}{|c|}{ Pollutants } & Data Sources \\
\hline \multirow[t]{3}{*}{ LAPs } & $\mathrm{SO}_{2}$ & \multirow{3}{*}{$\begin{array}{l}\text { (i) Statistical data on electricity and environment } \\
\text { (ii) Related databases, research reports, and academic articles }\end{array}$} \\
\hline & $\mathrm{NOx}$ & \\
\hline & PM & \\
\hline GHGs & $\mathrm{CO}_{2}$ & $\begin{array}{l}\text { (i) Government of the PRC, Ministry of Ecology and Environment: } \\
\mathrm{CO}_{2} \text { emission factors of the PRC's regional grid } \\
\text { (ii) Related database, research reports, and academic articles }\end{array}$ \\
\hline
\end{tabular}

$\mathrm{CO}_{2}=$ carbon dioxide, $\mathrm{GHG}=$ greenhouse gas, $\mathrm{LAP}=$ local air pollutant, $\mathrm{NOx}=$ nitrogen oxide, $\mathrm{PM}=$ particulate matter, $\mathrm{PRC}=\mathrm{People}$ 's Republic of China, $\mathrm{SO}_{2}=$ sulfur dioxide.

Source: The authors.

Table A1.3: Air Pollutant Equivalence $\left(\mathrm{AP}_{\text {eq }}\right)$ Normalizing Parameter

\begin{tabular}{|c|c|c|}
\hline \multicolumn{2}{|c|}{ Pollutant } & Data Sources \\
\hline \multirow[t]{5}{*}{ LAPs } & $\mathrm{SO}_{2}$ & \multirow[t]{5}{*}{ (i) Environmental Protection Tax, in the People's Republic of China } \\
\hline & NOx & \\
\hline & PM & \\
\hline & $\mathrm{CO}$ & \\
\hline & $\mathrm{HC}$ & \\
\hline GHGs & $\mathrm{CO}_{2}$ & (i) Carbon trading prices \\
\hline
\end{tabular}

$\mathrm{CO}=$ carbon monoxide, $\mathrm{CO}_{2}$ = carbon dioxide, $\mathrm{GHG}$ = greenhouse gas, $\mathrm{HC}=$ hydrocarbon, $\mathrm{LAP}=$ local air pollutant, $\mathrm{NOx}=$ nitrogen oxide, $\mathrm{PM}=$ particulate matter, $\mathrm{SO}_{2}=$ sulfur dioxide.

Source: The authors. 


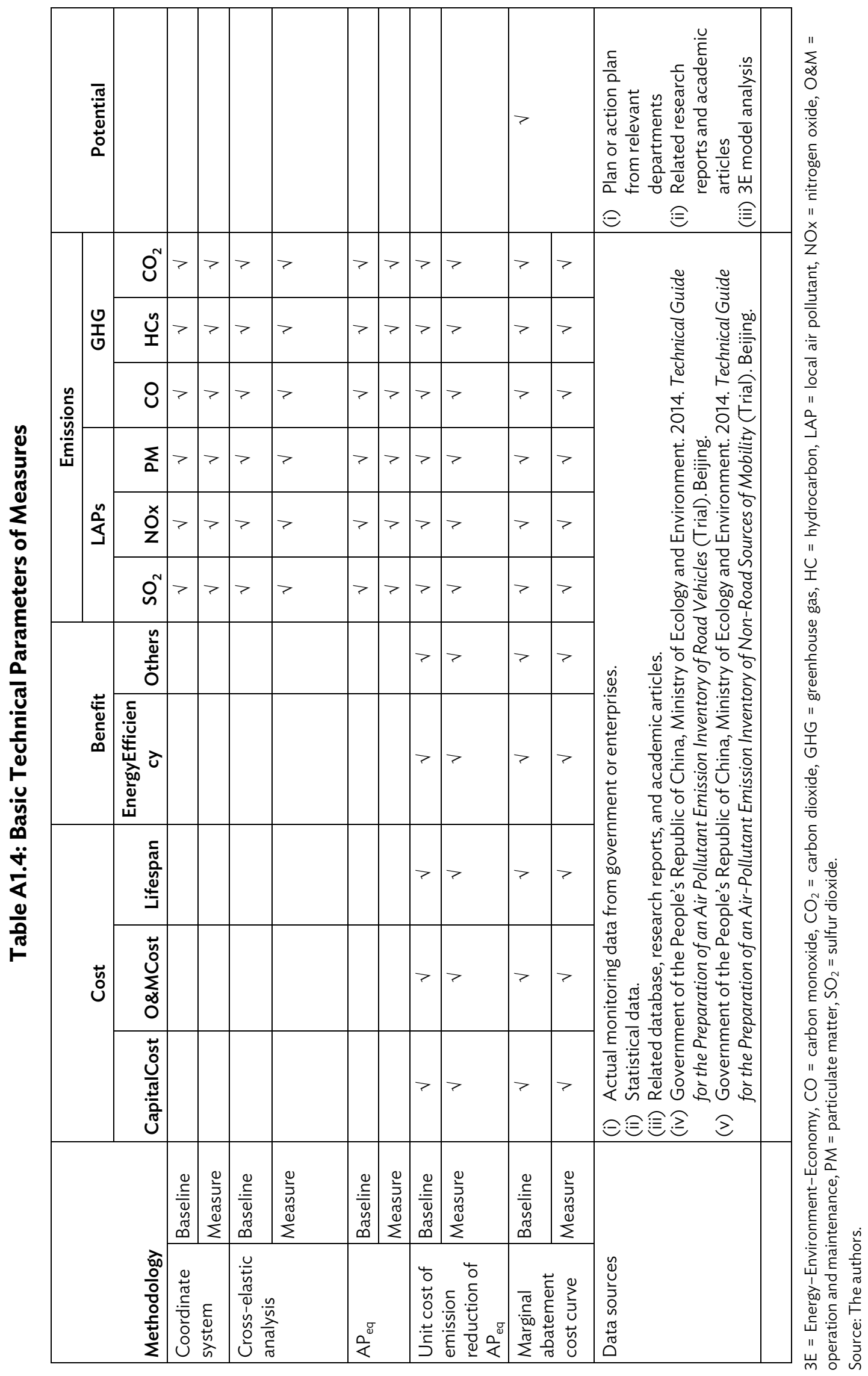




\section{Appendix 2: The Normalization Index and the Weighing Factors for the Transport Sector in the People's Republic of China}

Based on the characteristics of the local air pollutants (LAPs) and greenhouse gas (GHG) emissions generated by the transport sector, the main pollutants selected for this study were sulfur dioxide $\left(\mathrm{SO}_{2}\right)$, nitrogen oxide ( $\left.\mathrm{NOx}\right)$, carbon monoxide (CO), particulate matter (PM), hydrocarbons (HCs), and carbon dioxide $\left(\mathrm{CO}_{2}\right)$; while for the power industry (which involves indirect emissions), the main pollutants are $\mathrm{SO}_{2}, \mathrm{NOx}, \mathrm{PM}$, and $\mathrm{CO}_{2}$.

\section{A. Relative Weighing Factors of Local Air Pollutants and Greenhouse Gases}

The weighing factor of Local Air Pollutants $\mathrm{R}_{\mathrm{LAP}}$ and the weighing factor of Greenhouse Gases $\mathrm{R}_{\mathrm{GHG}}$ are key to decide the normalization of LAPs and GHGs into one indicator. As discussed at section III. METHODOLOGY OF CO-CONTROL EVALUATION, the difference of the impacts by LAPs and GHGs can be represented by the ratio of the economic values of their impacts, as shown below.

According to the Schedule of Tax Items and Tax Amounts of the Environmental Protection Tax, under the Environmental Protection Tax Law of the People's Republic of China (2018), the taxation rate for air pollutants ranges from $C N Y 1.2$ to $C N Y 12$ per unit of $A P_{\text {eq. }}$ In this case study, the average rate CNY6.0 per unit $A P_{\text {eq }}$ was selected as the reference to decide weighing factors.

In 2013, the National Development and Reform Commission of the People's Republic of China (PRC) launched seven pilot carbon emissions-trading schemes. By 31 December 2017, the accumulated $\mathrm{CO}_{2}$ emissions trading quota reached 470 million tons, and the total trading value reached $\mathrm{CNY} 12.494$ billion. The average carbon price was $\mathrm{CNY} 22.23 / \mathrm{tCO}_{2}$ (or $\mathrm{CNY} 0.02223 / \mathrm{kgCO}_{2}$-eq) which was selected as the reference to decide weighing factors.

The following formula was used to calculate the relative weighing factors of LAPs and GHGs:

$$
R_{L A P} / R_{G H G}=C N Y 6.0 / C N Y 0.02223=270
$$

This means that $270 \mathrm{~kg}$ of $\mathrm{CO}_{2}$-eq emission has the same environmental impact as one unit of $\mathrm{AP}_{\text {eq }}$ (or one $\mathrm{kg}$ of $\mathrm{CO}_{2}$-eq emission is equivalent to 0.00372 unit of $\mathrm{AP}_{\text {eq }}$ ), or equivalent to $0.95 \mathrm{~kg}$ of $\mathrm{SO}_{2}$ or $\mathrm{NO}_{2}$ in the current calculation framework.

\section{B. Local Air Pollution Contribution by Industry}

This section focuses on the air pollution contribution of $\mathrm{i}$ industry in $\mathrm{j}$ area, or Ai,j. Local pollutant emissions from different sources basically have different environmental impacts. For example, the same amount of NOx emitted from nonpoint automobile sources in an urban area generates much more serious health-damaging impacts than the same amount of NOx emitted from the high chimney stack of a power plant located in a rural area. This study tries to account for this difference by using a pollution contribution parameter, $\mathrm{Ai}, \mathrm{j}$, which is calculated here by referring to the contribution rate of particulate matter $2.5\left(\mathrm{PM}_{2.5}\right)$, instead of that for all the air pollutants. In the meantime, the $\mathrm{CO}_{2}$ contribution coefficient for the transport sector and the power industry are assumed to be the same. 
In the Gaussian equations for air pollution diffusion (Equation A.1), the ratios of ground-level pollutant concentration $(\mathrm{q})\left(\mathrm{mg} / \mathrm{m}^{3}\right)$ to the outlet concentration $(\mathrm{Q})\left(\mathrm{mg} / \mathrm{m}^{3}\right)$ of different air pollutants are assumed to be the same. In other words, there is a linear relationship between the ground-level and outlet concentrations.

$$
C(x, y, z)=\frac{Q}{2 \pi u \sigma_{y} \sigma_{z}}\left\{\exp \left(\frac{-(z-h)^{2}}{2 \sigma_{z}^{2}}\right)+\exp \left(\frac{-(z+h)^{2}}{2 \sigma_{z}^{2}}\right)\right\}\left\{\exp \left(\frac{-(y)^{2}}{2 \sigma_{y}^{2}}\right)\right\}
$$

where $C(x, y, z)=$ Pollutant concentration as a function of downwind position $(x, y, z) ; Q=$ Mass emission rate; $u=$ Wind speed evaluated at "effective" release height; $\sigma_{y}, \sigma_{z}=$ Corresponds to disk area in simple model (values depend upon downwind distance, $x$ ); $h=$ "Effective" stack height, including rise of the hot plume near the source.

The calculation of $\mathrm{PM}_{2.5}$ emissions should include primary $\mathrm{PM}_{2.5}$ (directly emitted from the sources) and secondary $\mathrm{PM}_{2.5}$ (generated from atmospheric chemical reactions). So, the total emissions of $\mathrm{PM}_{2.5}$ can be expressed theoretically as Eq A.2.

$$
Q_{j}=Q_{P M_{2.5}, j_{2.5}}+\sum \emptyset_{i} \times Q_{i, j}
$$

where $Q_{j}=$ the primary $P M_{2.5}$ and secondary $P M_{2.5}$ generated by industry $j ; Q_{P M_{2.5 j 2.5}}=$ the emissions of primary $\mathrm{PM}_{2.5}$ from industry $\mathrm{j}$; and $\emptyset i=$ the conversion coefficient of the secondary $\mathrm{PM}_{2.5}$ for pollutant i. According to the PRC's Technical Guidelines for Environmental Impact Assessment-Atmospheric Environment, $\emptyset_{S_{O} 2}$ is 0.58 and $\emptyset_{N O x}$ is $0.44 . Q_{i, j}=$ the emission of pollutant i from industry j;

According to the $\mathrm{PM}_{2.5}$ source-apportionment results released by several cities in the PRC, the pollutants brought in by vehicles from other regions have similar contribution ratios. Therefore, the average contribution rates of $\mathrm{PM}_{2.5}$ from power plants and from local transport (mainly motor vehicles and ships) can be determined.

Based on the 2013 data on $\mathrm{PM}_{2.5}$ pollutant source apportionment, the primary and secondary emissions of $\mathrm{PM}_{2.5}$ can be calculated by means of Eq. A.2.

The contribution coefficient of the power industry is theoretically expressed as Eq. A.3:

$$
\omega \frac{\eta_{\text {Tran }}}{Q_{\text {Tran }}}=\frac{\eta_{E L c}}{Q_{E L c}}
$$

where: $\eta_{\text {Tran }}, \eta_{\mathrm{Elc}}=$ the contribution rate of $\mathrm{PM}_{2.5}$ from the transport sector and power industry, according to the pollutant source apportionment; $Q_{\text {Tran, }} Q_{\text {Elc }}=$ total emissions of $\mathrm{PM}_{2.5}$ from the transport sector and power industry, including primary and secondary emissions; and $\omega=$ the contribution coefficient of the power industry (that of the transport industry is assumed to be 1). 
Table A2.1: Pollution-Source Analysis Results for Several Locations

(\%)

\begin{tabular}{|c|c|c|c|c|c|c|}
\hline $\begin{array}{l}\text { Location } \\
\text { (City or } \\
\text { Province) }\end{array}$ & Year(s) & $\begin{array}{l}\text { Regional } \\
\text { Transfer }\end{array}$ & Transportation & Coal & $\begin{array}{l}\text { Power } \\
\text { Industry }\end{array}$ & Notes \\
\hline \multirow[t]{2}{*}{ Beijing } & $2012-2013$ & $28-36$ & 31.1 & 22.4 & $\ldots$ & $\ldots$ \\
\hline & 2017 & 33 & 45.0 & 3.0 & $\ldots$ & $\ldots$ \\
\hline \multirow[t]{2}{*}{ Jinan } & $2010-2013$ & $20-32$ & 15.0 & 27.0 & $\ldots$ & $\ldots$ \\
\hline & 2017 & $26-34$ & 32.6 & 24.6 & $\ldots$ & $\ldots$ \\
\hline Guangzhou & 2016 & $\ldots$ & 25.2 & 19.9 & $\ldots$ & $\begin{array}{l}\text { Motor vehicles (16.3), ocean } \\
\text { shipping (8.9) }\end{array}$ \\
\hline Shanghai & $2012-2013$ & $16-36$ & 29.2 & 13.5 & $\ldots$ & $\ldots$ \\
\hline Tianjin & $2012-2014$ & $22-34$ & 27.0 & 20.0 & $\ldots$ & $\ldots$ \\
\hline $\begin{array}{l}\text { Henan } \\
\text { (province) }\end{array}$ & $\ldots$ & $\ldots$ & 23.0 & 31.0 & $\ldots$ & $\ldots$ \\
\hline Shijiazhuang & 2013-2014 & $23-30$ & 15.0 & 28.5 & $\ldots$ & $\ldots$ \\
\hline Nanjing & 2014 & $20-38$ & 24.6 & 27.4 & $\ldots$ & $\ldots$ \\
\hline Hangzhou & 2014 & $18-38$ & 28.0 & 18.8 & $\ldots$ & $\ldots$ \\
\hline Wuhan & $\ldots$ & $\ldots$ & 27.0 & 20.0 & $\ldots$ & $\ldots$ \\
\hline Baoding & $\ldots$ & $\ldots$ & 20.3 & 21.2 & $\ldots$ & $\ldots$ \\
\hline Shenzhen & 2014 & $\ldots$ & 52.0 & $\ldots$ & 8.0 & $\begin{array}{l}\text { Motor vehicles (41.0), } \\
\text { ocean shipping (11.0), power } \\
\text { industry (8.0) }\end{array}$ \\
\hline Tangshan & 2012 & $\ldots$ & 9.5 & 17.7 & 7.5 & $\begin{array}{l}\text { Motor vehicles (9.5), power } \\
\text { industry (7.5) }\end{array}$ \\
\hline Changzhou & 2012 & $21-33$ & 22.0 & 23.0 & 12.2 & $\begin{array}{l}\text { Power industry (12.2), moving } \\
\text { source ( } 22.0 \text {, including gasoline } \\
\text { vehicles, diesel vehicles, and } \\
\text { non-road machinery }\end{array}$ \\
\hline Ningbo & 2012-2013 & $\ldots$ & 20.0 & $\ldots$ & 16.0 & $\begin{array}{l}\text { Power industry (16.0), } \\
\text { motor vehicles (11.0), shipping } \\
\text { industry (9.0) }\end{array}$ \\
\hline Cangzhou & 2014 & $\ldots$ & 19.2 & 35.6 & 4.7 & $\begin{array}{l}\text { Coal-fired power industry (4.7), } \\
\text { motor vehicles (19.2) }\end{array}$ \\
\hline Average & $\ldots$ & $\ldots$ & 24.5 & $\ldots$ & 9.7 & $\begin{array}{l}\text { The average of five cities } \\
\text { (Shenzhen, Tangshan, Changzhou, } \\
\text { Ningbo, Cangzhou) }\end{array}$ \\
\hline
\end{tabular}

... = data not available.

Source Official website of city environmental protection bureaus. 


\section{Table A2.2: Calculations of Particulate Matter 2.5 Contribution Coefficients for the Transport and Power Sectors}

\begin{tabular}{|c|c|c|c|c|c|c|c|}
\hline \multirow{2}{*}{\multicolumn{2}{|c|}{ Sector }} & \multicolumn{4}{|c|}{$\begin{array}{c}\text { Emissions } \\
(10,000 \text { tons })\end{array}$} & \multirow{3}{*}{$\begin{array}{c}\text { Contribution } \\
\text { Rate of } \mathrm{PM}_{2.5} \\
(\%)\end{array}$} & \multirow{3}{*}{$\begin{array}{c}\begin{array}{c}\text { Contribution } \\
\text { Coefficient } \\
\left(A_{i, j}\right)\end{array} \\
\ldots\end{array}$} \\
\hline & & \multirow{2}{*}{$\begin{array}{l}\mathrm{PM}_{2.5} \\
59.4\end{array}$} & \multirow{2}{*}{$\frac{\mathrm{SO}_{2}}{12.9}$} & \multirow{2}{*}{$\frac{\text { NOx }}{640.6}$} & \multirow{2}{*}{$\begin{array}{r}\begin{array}{c}\text { Total } \\
\mathrm{PM}_{2.5}\end{array} \\
348.7\end{array}$} & & \\
\hline Transport & Vehicles & & & & & & \\
\hline & Shipping & 10.4 & 69.2 & 106.5 & 97.4 & $\ldots$ & $\ldots$ \\
\hline & Total & 69.8 & 82.0 & 747.1 & 446.2 & 24.6 & 1.0 \\
\hline \multicolumn{2}{|l|}{ Power } & 218.8 & 782.7 & 964.6 & $1,097.2$ & 9.7 & 0.2 \\
\hline \multicolumn{2}{|c|}{ Transfer coefficient of $\mathrm{PM}_{2.5}$} & 1.0 & 0.6 & 0.4 & & & $\ldots$ \\
\hline
\end{tabular}

$\ldots=$ data not available, $\mathrm{NOx}=$ nitrogen oxide, $\mathrm{PM}_{2.5}=$ particulate matter $2.5, \mathrm{SO}_{2}=$ sulfur dioxide.

Note: An empty cell indicates that the column head does not apply.

Sources: China Vehicle Emission Control Annual Report, released by Ministry of Environmental Protection of PRC; Ministry of Environmental Protection of PRC; and the authors.

\section{Determining the Values of the Weighing Factors}

In Table A2.3, the weighing factors $\alpha, \beta, \gamma, \delta$, and $\bigotimes$, are determined according to the Schedule of Tax Items and Tax Amounts of the Environmental Protection Tax, under the PRC's Environmental Protection Tax Law (2018), and according to the concept of GWP, from Climate Change 2014: Synthesis Report, released by the Intergovernmental Panel on Climate Change (IPCC 2014).

Table A2.3: Values of the Weighing Factors

\begin{tabular}{|l|c|c|c|c|c|}
\hline Air pollutant & Index & $\begin{array}{c}\text { Air Pollution } \\
\text { Equivalence } \\
\text { Coefficient }\end{array}$ & GHG & Index & $\begin{array}{c}\text { Global Warming } \\
\text { Potential }\end{array}$ \\
\hline $\mathrm{SO}_{2}$ & $\alpha$ & $1 / 0.95$ & $\mathrm{CO}_{2}$ & $\epsilon$ & 1 \\
\hline $\mathrm{NOx}$ & $\beta$ & $1 / 0.95$ & $\ldots$ & $\ldots$ & $\ldots$ \\
\hline $\mathrm{CO}$ & $\gamma$ & $1 / 16.70$ & $\ldots$ & $\ldots$ & $\ldots$ \\
\hline $\mathrm{PM}$ & $\delta$ & $1 / 2.18^{\mathrm{a}}$ & $\ldots$ & $\ldots$ & $\ldots$ \\
\hline $\mathrm{HCS}$ & $\varepsilon$ & $1 / 0.95^{\mathrm{b}}$ & $\ldots$ & $\ldots$ & $\ldots$ \\
\hline
\end{tabular}

$\ldots=$ data not available, $\mathrm{CO}=$ carbon monoxide, $\mathrm{CO}_{2}=$ carbon dioxide, $\mathrm{GHG}=$ greenhouse gas, $\mathrm{HC}=$ hydrocarbon, $\mathrm{NOx}=$ nitrogen oxide, $\mathrm{PM}=$ particulate matter, $\mathrm{SO}_{2}=$ sulfur dioxide.

Note: An empty cell indicates that the column head does not apply.

a The air pollution equivalence coefficient of PM is referred to as "smoke dust."

${ }^{\mathrm{b}}$ The air pollution equivalent coefficient of HC, categorized as volatile organic compounds (VOCs), is given the value of 0.95 , based on Government of the People's Republic of China. 2015. Pilot Measures for Charging Volatile Organic Pollutants Emission. Beijing.

Source: Schedule of Tax Items and Tax Amounts of the Environmental Protection Tax, under the People's Republic of China's Environmental Protection Tax Law (2018); Climate Change 2014: Synthesis Report, released by the Intergovernmental Panel on Climate Change (2014). 


\section{Co-control of Air Pollutant Equivalence (APeq) Equations}

For the transport sector:

$A P_{e q}=1 \times 1 \times\left(Q_{S O 2} / 0.95+Q_{N O x} / 0.95+Q_{C O} / 16.7+Q_{P M} / 2.18+Q_{H C} / 0.95+\cdots\right)+0.00372 \times\left(1 \cdot Q_{C O 2}+\cdots\right)$

For power industry (indirect emissions):

$$
A P_{e q}=1 \times 0.16 \times\left(Q_{S O 2} / 0.95+Q_{N O x} / 0.95+Q_{P M} / 2.18\right)+0.00372 \times\left(1 \cdot Q_{C O 2}+\cdots\right)
$$

where $\mathrm{AP}_{\mathrm{eq}}=$ air pollutant equivalence, $\mathrm{Q}_{\mathrm{SO} 2}=\mathrm{SO}_{2}$ emissions, $\mathrm{Q}_{\mathrm{NOx}}=\mathrm{NOx}$ emissions, $\mathrm{Q}_{\mathrm{CO}}=\mathrm{CO}$ emissions, $Q_{P M}=P M$ emissions, $Q_{H C}=H C$ emissions, and $Q_{\mathrm{CO} 2}=\mathrm{CO}_{2}$ emissions.

Table A3.1 provides the emission factors of different LAPs from power generation, while Table A3.2 provide emissions factors of LAPs generated from different vehicles. 


\section{Appendix 3: Emission Factors in this Case Study}

Table A3.1: Emission factors from Power Generation, 2017

\begin{tabular}{|l|c|}
\hline Pollutant & $\begin{array}{c}\text { Emission factor } \\
(\mathrm{g} / \mathrm{kWh})\end{array}$ \\
\hline Carbon monoxide $(\mathrm{CO})$ & $\ldots$ \\
\hline Sulfur oxide $(\mathrm{SO})$ & 0.187 \\
\hline Nitrogen oxide $(\mathrm{NO})$ & 0.178 \\
\hline Particulate matter $2.5\left(\mathrm{PM}_{2.5}\right)$ & 0.041 \\
\hline Particulate matter 10 $\left(\mathrm{PM}_{10}\right)$ & $\ldots$ \\
\hline Carbon dioxide $\left(\mathrm{CO}_{2}\right)$ & 599.000 \\
\hline
\end{tabular}

... = data not available, $\mathrm{g}=$ grams, $\mathrm{kWh}=$ kilowatt-hour.

Source: China Electricity Council, People's Republic of China.

Table A3.2: Emissions Factors for Vehicles

\begin{tabular}{|c|c|c|c|c|c|c|c|}
\hline \multirow{2}{*}{\multicolumn{2}{|c|}{ Vehicle Type }} & \multicolumn{5}{|c|}{$\begin{array}{l}\text { Emission Factor } \\
(\mathrm{g} / \mathbf{k m})\end{array}$} & \multirow[b]{2}{*}{ Fuel } \\
\hline & & \multirow{2}{*}{$\frac{\mathrm{CO}}{6.71}$} & \multirow{2}{*}{$\frac{H C}{0.663}$} & \multirow{2}{*}{$\frac{\text { NOx }}{0.409}$} & \multirow{2}{*}{$\frac{\mathrm{PM}_{2.5}}{0.026}$} & \multirow{2}{*}{$\frac{\mathrm{PM}_{10}}{0.029}$} & \\
\hline Minibus & China I & & & & & & Gasoline \\
\hline & China II & 2.52 & 0.314 & 0.324 & 0.011 & 0.012 & \\
\hline & China III & 1.18 & 0.191 & 0.100 & 0.007 & 0.008 & \\
\hline & China IV & 0.68 & 0.075 & 0.032 & 0.003 & 0.003 & \\
\hline & China V & 0.46 & 0.056 & 0.017 & 0.003 & 0.003 & \\
\hline \multirow[t]{3}{*}{ Motorcycle } & China I & 8.96 & 0.990 & 0.140 & 0.018 & 0.020 & \\
\hline & China II & 2.58 & 0.530 & 0.150 & 0.008 & 0.009 & \\
\hline & China III & 1.11 & 0.210 & 0.100 & 0.003 & 0.003 & \\
\hline \multirow[t]{5}{*}{ Small truck } & China I & 26.16 & 3.324 & 2.006 & 0.060 & 0.067 & \\
\hline & China II & 21.54 & 2.210 & 1.656 & 0.018 & 0.020 & \\
\hline & China III & 5.16 & 0.610 & 0.534 & 0.011 & 0.012 & \\
\hline & China IV & 2.37 & 0.169 & 0.229 & 0.006 & 0.007 & \\
\hline & China V & 2.37 & 0.169 & 0.172 & 0.006 & 0.007 & \\
\hline \multirow{5}{*}{$\begin{array}{l}\text { Medium-sized } \\
\text { truck }\end{array}$} & China I & 4.24 & 1.612 & 7.479 & 0.905 & 1.006 & \multirow[t]{5}{*}{ Diesel } \\
\hline & China II & 4.63 & 0.421 & 6.221 & 0.273 & 0.303 & \\
\hline & China III & 2.09 & 0.203 & 6.221 & 0.171 & 0.190 & \\
\hline & China IV & 1.65 & 0.103 & 4.354 & 0.099 & 0.110 & \\
\hline & China V & 1.65 & 0.103 & 3.701 & 0.020 & 0.022 & \\
\hline
\end{tabular}


Table A3.2 continued

\begin{tabular}{|c|c|c|c|c|c|c|c|}
\hline \multirow{2}{*}{\multicolumn{2}{|c|}{ Vehicle Type }} & \multicolumn{5}{|c|}{$\begin{array}{c}\text { Emission Factor } \\
(\mathrm{g} / \mathrm{km})\end{array}$} & \multirow{3}{*}{ Fuel } \\
\hline & & \multirow{2}{*}{$\begin{array}{l}\mathrm{CO} \\
5.79\end{array}$} & \multirow{2}{*}{$\frac{\mathrm{HC}}{0.897}$} & \multirow{2}{*}{$\begin{array}{l}\text { NOx } \\
9.589\end{array}$} & \multirow{2}{*}{$\begin{array}{l}\mathrm{PM}_{2.5} \\
0.623\end{array}$} & \multirow{2}{*}{$\begin{array}{l}\mathrm{PM}_{10} \\
0.692\end{array}$} & \\
\hline Heavy truck & China I & & & & & & \\
\hline & China II & 3.08 & 0.520 & 7.934 & 0.502 & 0.558 & \\
\hline & China III & 2.79 & 0.255 & 7.934 & 0.243 & 0.270 & \\
\hline & China IV & 2.20 & 0.129 & 5.554 & 0.138 & 0.153 & \\
\hline & China V & 2.20 & 0.129 & 4.721 & 0.027 & 0.030 & \\
\hline \multirow[t]{5}{*}{ Large bus } & China I & 9.86 & 0.576 & 11.156 & 0.983 & 1.092 & \\
\hline & China II & 8.68 & 0.351 & 9.892 & 0.882 & 0.980 & \\
\hline & China III & 6.74 & 0.283 & 9.892 & 0.395 & 0.439 & \\
\hline & China IV & 3.25 & 0.107 & 9.892 & 0.252 & 0.280 & \\
\hline & China V & 1.62 & 0.054 & 8.640 & 0.126 & 0.140 & \\
\hline
\end{tabular}

$\mathrm{CO}=$ carbon monoxide, $\mathrm{HC}=$ hydrocarbon, $\mathrm{g}=$ grams, $\mathrm{km}=$ kilometer, $\mathrm{NOx}=$ nitrogen oxide, $\mathrm{PM}_{2.5}=$ particulate matter $2.5, \mathrm{PM} 10=$ particulate matter 10.

Note: In the second column, the roman numerals after "China" refer to the stage of emissions standards reduction in the People's Republic of China.

Source: Henan Provincial Department of Transportation 


\section{REFERENCES}

Climate Action Tracker. China: Country Summary. https://climateactiontracker.org/countries/china/ (updated 2 December 2019).

- EU: Pledges and Targets. https://climateactiontracker.org/countries/eu/pledges-andtargets/(updated 2 December 2019).

Diesel Technology Forum. About Clean Diesel: What is SCR? What is Selective Catalytic Reduction? https://www.dieselforum.org/about-clean-diesel/what-is-scr (accessed 16 July 2018).

DieselNet. Emission Standards: EU; Cars; Greenhouse Gas Emissions. https://www.dieselnet. com/standards/eu/ghg.php (revised May 2019).

- Emission Standards: United States: Cars and Light-Duty Trucks; Tier 3. https://www.dieselnet. com/standards/us/ld_t3.php (revised August 2016).

- Emission Standards: United States: Heavy-Duty Onroad Engines. https://www.dieselnet. com/standards/us/hd.php (revised December 2017).

European Commission. Climate Action: Reducing $\mathrm{CO}_{2}$ Emissions from Passenger Cars. https://ec.europa.eu/clima/policies/transport/vehicles/cars_en (accessed 16 July 2018).

European Environment Agency. Emissions of Air Pollutants from Transport. https://www.eea.europa. eu/data-and-maps/indicators/transport-emissions-of-air-pollutants-8/transport-emissions-of-airpollutants-5 (modified 22 November 2018).

Eurostat. Statistics Explained: Greenhouse Gas Emission Statistics-Emission Inventories. http://ec.europa.eu/eurostat/statistics-explained/index.php/Greenhouse_gas_emission_statistics__emission_inventories (modified 15 April 2020).

Fioretti, Julia. 2018. EU States Call for Ambitious Truck $\mathrm{CO}_{2}$ Emissions Targets. Reuters. 7 May. https://www.reuters.com/article/us-eu-trucks-emissions/eu-states-call-for-ambitious-truck-co2emissions-targets-idUSKBN1I80VS.

Gao, Yubing, Mao Xianqiang, Gabriel Corsetti, Wei Yi. 2014. Assessment of Co-control Effects for Air pollutants and Green House Gases in Urban Transport: A Case Study in Urumqi. China Environmental Science 34 (11): pp. 2985-2992.

Government of Canada. 2013. Heavy-Duty Vehicle and Engine Greenhouse Gas Emission Regulations. Canada Gazette Part II, Vol.147, No. 6. http://gazette.gc.ca/rp-pr/p2/2013/2013-03-13/html/sordors24-eng.html.

2018. Regulations Amending the Heavy-Duty Vehicle and Engine Greenhouse Gas Emission Regulations and Other Regulations Made Under the Canadian Environmental Protection Act, 1999. 
Canada Gazette Part II, Vol. 152, No. 11. http://gazette.gc.ca/rp-pr/p2/2018/2018-05-30/html/sordors98-eng.html.

Greene, David L., Howard H. Baker, and Steven E. Plotkin. 2011. Reducing Greenhouse Gas Emissions from US Transportation. Arlington, VA, USA: Pew Center on Global Climate Change. https://www.c2es.org/site/assets/uploads/2011/01/reducing-ghg-emissions-from-transportation.pdf.

Greszler, Anthony. 2014. The Role of the Internal Combustion Engine in Our Energy Future. https://www.energy.gov/sites/prod/files/2014/03/f8/deer11_greszler.pdf (accessed 15 July 2018).

Hu, Tao, Mao Xianqiang, Qian Yi, Xing Youkai, Zeng An. 2016. Co-control of Air Pollutants and GHGsA Case Study in Urumqi. Beijing: China Environmental Science Press.

Hu, Tao, Tian Chunxiu, and Mao Xianqianq. 2012. Co-control: Lookback and Lookforward. Environment and Sustainable Development 37 (1): pp. 25-29.

Intergovernmental Panel on Climate Change. 2001. Climate Change 2001: The Scientific Basis. Contribution of Working Group I to the Third Assessment Report of the Intergovernmental Panel on Climate Change. Cambridge, United Kingdom, and New York: Cambridge University Press. https://www.ipcc.ch/site/assets/uploads/2018/03/WGI_TAR_full_report.pdf.

2014. Climate Change 2014: Synthesis Report. Contribution of Working Groups I, II and III to the Fifth Assessment Report of the Intergovernmental Panel on Climate Change. Geneva. https://www.ipcc.ch/site/assets/uploads/2018/02/SYR_AR5_FINAL_full.pdf.

International Council on Clean Transportation (ICCT). 2014. Policy Update: Final Phase 2 China Fuel Consumption Standard for Commercial Heavy-Duty Vehicles. May. http://www.theicct.org/sites/ default/files/publications/ICCTupdate_ChinaPhase2_june2014.pdf.

2017. Policy Update: Fuel Consumption Standards for Heavy-Duty Vehicles in India. December. https://www.theicct.org/sites/default/files/publications/ICCT_India-HDV-fuel-consumption_policyupdate_20171207.pdf.

2018. Policy Update: The European Commission's Proposed $\mathrm{CO}_{2}$ Standards for Heavy-Duty Vehicles. June. https://www.theicct.org/sites/default/files/publications/EC_Proposed_CO2_HDV_ Policy_Update_20180626.pdf.

International Energy Agency. 2010. Energy Technology Perspective 2010: Scenarios and Strategies to 2050. Paris.

International Organization for Standardization. 2006. 14040:2006(en): Environmental ManagementLife Cycle Assessment-Principles and Framework. https://www.iso.org/obp/ui/\#iso:std:iso:14040:ed2:v1:en.

International Transport Forum. 2018. Transport $\mathrm{CO}_{2}$ and the Paris Climate Agreement: Reviewing the Impact of Nationally Determined Contributions. Paris. https://www.itf-oecd.org/sites/default/files/docs/ transport-co2-paris-climate-agreement-ndcs.pdf. 
Kim Oanh, Nguyen Thi, Lai Nguyen Huy, Didin Agustian Permadi, Eric Zusman, Ryoko Nakano, Sudarmanto Budi Nugroho, Puji Lestari, and Asep Sofyan. 2019. Assessment of urban passenger fleet emissions to quantify climate and air quality co-benefits resulting from potential interventions. Carbon Management 9 (4): pp. 367-381.

Majewski, W. Addy. Selective Catalytic Reduction. DieselNet Technology Guide. https://www.dieselnet.com/tech/cat_scr.php (revised May 2005).

Majewski, W. Addy, and Hannu Jääskeläinen. 2015. Engine Emission Control. DieselNet Technology Guide. https://www.dieselnet.com/tech/engine_design.php (revised 2019).

Ministry of Ecology and Environment of the People's Republic of China. 2018. Second Biennial Update Report on Climate Change of the People's Republic of China. Beijing: Ministry of Ecology and Environment of the People's Republic of China.

2019. China Mobile Source Environmental Management Annual Report 2019. Beijing: Ministry of Ecology and Environment of the People's Republic of China. http://www.mee.gov.cn/xxgk2018/xxgk/ xxgk15/201909/t20190904_732374.html (in Chinese).

Ministry of Ecology and Environment of the People's Republic of China, National Bureau of Statistics, and the Ministry of Agriculture and Rural Affairs. 2020. Bulletin of the Second National Census of Pollution Sources. Beijing: Ministry of Ecology and Environment of the People's Republic of China, National Bureau of Statistics, and the Ministry of Agriculture and Rural Affairs. http://www.mee.gov.cn/xxgk2018/xxgk/xxgk01/202006/t20200610_783547.html (in Chinese).

Ministry of Finance of the People's Republic of China, National Development and Reform Commission, and the Ministry of Ecology and Environment. 2015. Pilot Measures for Charging Volatile Organic Pollutants Emission. Beijing: Ministry of Finance, National Development and Reform Commission, and the Ministry of Ecology and Environment.

National People's Congress of the People's Republic of China. 2018. Environmental Protection Tax Law of the People's Republic of China. [EB/OL] [2018-11-05] http://www.npc.gov.cn/npc/xinwen/201811/05/content_2065629.htm.

Tang, Wei, Zheng Siwei, He Ping, Xu Hailan, Gu Yu, Yan Lanling, Yang Qiang, Huang Cheng, and Shen Yang. 2019. Research on Synergy Effect of Motor Vehicle Exhaust Emission Control Based on Scenario Analysis: Study on the Co-Benefit of Motor Vehicle Emission Control Based on Scenario Analysis in Hangzhou. Acta Scientiae Circumstantiae 39(6): pp. 2033-2042.

Transport Policy. 2018. EU: Light-Duty; Emissions. https://www.transportpolicy.net/standard/eu-lightduty-emissions/ (accessed 15 July 2018).

United States (US) Energy Information Administration. 2016. International Energy Outlook 2016. Washington, DC. https://www.eia.gov/outlooks/ieo/pdf/0484(2016).pdf.

2017. Today in Energy: Power Sector Carbon Dioxide Emissions Fall Below Transportation Sector Emissions. 19 January. https://www.eia.gov/todayinenergy/detail.php?id=29612. 
US Environmental Protection Agency (EPA). EPA Analysis of the Transportation Sector: Greenhouse Gas and Oil Reduction Scenarios. https://www.epa.gov/transportation-air-pollution-and-climatechange/epa-analysis-transportation-sector-greenhouse-gas (updated 18 March 2010).

2016. Light-Duty Vehicles and Light-Duty Trucks: Tier 0, Tier 1, National Low Emission Vehicle (NLEV), and Clean Fuel Vehicle (CFV) Exhaust Emission Standards. March. https://nepis.epa.gov/Exe/ZyPDF.cgi?Dockey=P10009ZP.pdf.

Smog, Soot, and Other Air Pollution from Transportation. https://www.epa.gov/transportationair-pollution-and-climate-change/smog-soot-and-local-air-pollution (accessed 15 July 2018).

US EPA and the US Department of Transportation, National Highway Traffic Safety Administration. 2011. Greenhouse Gas Emissions Standards and Fuel Efficiency Standards for Medium- and HeavyDuty Engines and Vehicles, Final Rules. Federal Register, Vol. 76, No. 179, 15 September. https://www.govinfo.gov/content/pkg/FR-2011-09-15/pdf/2011-20740.pdf.

2012. 2017 and Later Model Year Light-Duty Vehicle Greenhouse Gas Emissions and Corporate Average Fuel Economy Standards, Final Rule. Federal Register, Vol. 77, No. 199, 15 October. https://www.govinfo.gov/content/pkg/FR-2012-10-15/pdf/2012-21972.pdf.

2016. Greenhouse Gas Emissions Standards and Fuel Efficiency Standards for Medium- and Heavy-Duty Engines and Vehicles_Phase 2, Final Rule. Federal Register, Vol. 81, No. 206, 25 October. https://www.govinfo.gov/content/pkg/FR-2016-10-25/pdf/2016-21203.pdf.

2018. The Safer Affordable Fuel-Efficient (SAFE) Vehicles Rule for Model Years 2021-2026 Passenger Cars and Light Trucks, Notice of Proposed Rulemaking. Federal Register, Vol. 83, No. 165, 24 August. https://www.govinfo.gov/content/pkg/FR-2018-08-24/pdf/2018-16820.pdf. 


\section{Air Pollutants and Greenhouse Gas Emissions Co-control Evaluation in the People's Republic of China}

Local air pollutants (LAPs), such as carbon monoxide, hydrocarbon, sulfur oxide, nitrogen oxide, ozone, and particulate matter, as well as greenhouse gas (GHG) emissions from the transport sector are rapidly increasing in the People's Republic of China. Various measures to control LAPs have been implemented in the country, along with the adoption of strategies to mitigate GHG emissions. The connection between LAP and GHG emission control and reduction offers an opportunity to address both problems simultaneously. This paper presents a methodology that measures the benefits of co-control evaluation on mitigating LAP and GHG emissions. It highlights the methodology's potential to help maximize measures and strategies that have significant co-control effects.

\section{About the Asian Development Bank}

ADB is committed to achieving a prosperous, inclusive, resilient, and sustainable Asia and the Pacific, while sustaining its efforts to eradicate extreme poverty. Established in 1966, it is owned by 68 members -49 from the region. Its main instruments for helping its developing member countries are policy dialogue, loans, equity investments, guarantees, grants, and technical assistance. 